Chapter 12

\title{
New Advances in the Diagnosis of Canine Visceral Leishmaniasis
}

\author{
Patrícia Sampaio Tavares Veras, \\ Deborah Bittencourt Mothé Fraga, \\ Manuela da Silva Solcà and \\ Carlos Eduardo Sampaio Guedes \\ Additional information is available at the end of the chapter \\ http://dx.doi.org/10.5772/57573
}

\section{Introduction}

Visceral leishmaniasis (VL) is a serious public health problem of great medical and veterinary importance. This disease is endemic in Brazil and in many other countries of Latin America, Asia, Africa and Europe (1). According to recent review (2), approximately 0.2 to 0.4 million cases of VL occur each year and although worldwide distributed, higher prevalence of the disease is concentrated in six countries, including India, Bangladesh, Sudan, South Sudan, Ethiopia and Brazil, that undertake for more than $90 \%$ of the cases. The clinical importance of VL resides in the severity of the disease that results in death of unrecognized cases and even for individuals with treatment access, death occurs in 10 to $20 \%$ of the cases [2-8].

Most of the VL cases are caused by the Leishmania species from Leishmania donovani complex. Parasites from the Leishmania genus are diphasic and are transmitted as promastigote form to vertebrate hosts through the bites of female sand flies [9-12]. The genetic similarities between Old World and New World strains, respectively, of L. infantum and L. infantum (syn. chagasi) from different regions in Latin America, indicate these parasites belong to the same origin $[11,12]$.

The notion that dogs are the main urban domestic reservoir for this Leishmania in certain part of the globe is supported by the facts including: i) cases of canine visceral leishmaniasis (CVL) have been reported in 50 of the 88 countries where VL is endemic [13], ii) canine cases precede the onset of human cases [14], iii) high rates of prevalence in dogs, and iv) frequency of parasites is high in dog skin [15-18]. 
Control strategies include performing accurate and early diagnosis of CVL to identify infected animals $[19,20]$. CVL diagnosis is a difficult task since clinical signs of the disease in dogs can be confused with other diseases [19]. In endemic areas, a large percentage of infected animals are asymptomatic or present low number of discrete signs. The role these animals play in parasite transmission is still largely unknown. Several diagnostic strategies have been implemented based on parasitological, serological or molecular methods in association with clinical and epidemiological parameters [21]. Parasite culturing has been considered as gold standard for disease diagnosis [22, 23]. Although offering a high specificity since allows parasite identification, it offers very low sensitivity, besides it is laborious, time-consuming and largely dependent on the expertise of the observer [24, 25].

Serological tests are the most common diagnostic method employed for CVL diagnosis [3]. Several serological methods have been implemented for diagnosis of CVL, including direct agglutination assay (DAT), enzyme linked immunoassay (ELISA) and indirect immunofluorescent antibody test (IFI) [26]. However, most of these classical serological tests present important limitations for CVL diagnosis, including high consumption of time, and lack of sensitivity and specificity, mainly when animals present low antibody titers. This causes underestimation of disease, reflecting in failures in control measures, as well as the maintenance of infected untreated dogs in endemic areas [27, 28]. New methods based on immunochromatography have been implemented for serodiagnosis of CVL and have shown excellent results [29]. These techniques offer several advantages since they are rapid tests easily performed even in field areas, and more specific since they use recombinant DNA technology that additionally facilitates reproducibility and large-scale production. These advantages result in better identification of infected dogs. However, the efficacy of immunochromatographic techniques for CVL diagnosis needs to be improved [30]. In Brazil, a rapid test based in dual path platform (TR DPP ${ }^{\circledR} \mathrm{LVC}$ - Biomanguinhos) had been recently implemented as screening test for CVL. This technique seems to be adequate to disease diagnosis in public health system. However, the TR DPP ${ }^{\circledR}$ VC has shown an excellent performance identifying $98 \%$ of symptomatic dogs, it showed less efficacy for diagnosis of asymptomatic dogs (47\%) [31]. Since there is evidence that asymptomatic dogs can participate in natural transmission cycle of VL, new strategies should be implemented in order to improve CVL diagnosis [16, 32-34]. For serological diagnosis one strategy can be the development of rapid tests based on impregnation of multi-antigen that would offer more sensitivity, as well specificity.

Finally, it would be important to include more specific confirmatory tests for control strategies that can be advantageous to diagnose inconclusive cases. There is evidence that molecular diagnosis of Leishmania spp. provides high levels of sensitivity and specificity when compared to other diagnostic methods $[7,17]$. The use of quantitative methods in molecular level allows not only a more accurate detection but also monitoring tissue parasite load in dogs following anti-leishmanial treatment [35-37].

\section{Importance of CVL diagnosis}

Since the discovery of canine visceral leishmaniasis (CVL) in Tunisia by Nicolle \& Comte (1908), several reports have shown that dog and man share a common etiologic agent. The 
notion that dog is the main reservoir of visceral leishmaniasis (VL) in urban centers [38] is supported by several evidences including the high cutaneous parasitism observed in dogs infected by Leishmania [15-18], the high rates of prevalence observed among dogs in endemic areas, and the observation that the appearance of canine cases precedes the emergence of human cases [14]. Some studies conducted in endemic regions, where VL occurs in a zoonotic cycle, point to a prevalence of approximately $20 \%$ of VL-positive dogs, as described in China [39], Greece [40], and Mexico [41]. In other endemic areas, rates of Leishmania infection detected in dogs range between 60 and 80\% [4, 42-44]. However, in spite of the high prevalence of Leishmania infection, not all dogs exhibit signs of clinical disease and sick dogs may display clinical signs of variable intensity $[4,42,45]$. Differences in clinical manifestations among dogs as the number of clinical signs and the time to onset of the disease may vary depending on the individual immune response of the infected dog. Three forms of progression of infection by L. infantum have been described: about $46 \%$ of infected dogs acquire the infection and develop the disease immediately, another $44 \%$ of dogs develop the disease later and $10 \%$ of them never develop CVL [46-48]. Similar to that which occurs in humans, characteristics such as genetic factors, age and nutritional status may influence the progression of VL in dogs $[13,49,50]$.

Some studies have shown a correlation between the presence of clinical signs in infected animals and transmissibility of the parasite to the vector and, consequently, a correlation with the occurrence of human cases [16, 32, 51]. In accordance with these studies, Travi et al. (2001) and Verçosa et al. (2008) showed that asymptomatic dogs did not transmit the parasite to the vector $[38,51]$. There is not a consensus about this idea, since there is a wide variation in the rates of infectivity (70 to $90 \%$ ) between asymptomatic and symptomatic dogs. Studies show that, regardless of the clinical presentation, any dog has the ability to transmit Leishmania to the vector, even though the symptomatic animals are more likely to disseminate the disease $[16,32,52,53]$, being more capable of transmitting the parasite to the vector and, consequently, to another dog or a human $[33,34,54,55]$. Based on studies showing that the dog can transmit the disease regardless of its clinical form, in some countries such as Brazil, dog culling is recommended as a control strategy. This control measure is not well accepted, having its effectiveness questioned and demanding studies to increase the diagnostic methods performance. Additionally, identification of new antigens will allow not only improvement of diagnosis, but also differentiation of dogs that transmit, from those that do not transmit the parasite in an endemic area.

\section{Visceral leishmaniasis diagnosis in dogs}

The diagnosis of VL in the dog must consider the association between clinical, laboratory and epidemiological data. As discussed above, clinical diagnosis is problematic and difficult for veterinarians to perform due to the great variability of clinical signs that Leishmania-infected dogs may present, as long as to its similarity with clinical profiles of other diseases. In clinical practice, identification of characteristic manifestations should be confirmed by ascertaining the infection using laboratory techniques [56] that vary in accuracy $[57,58]$. 
There are several laboratorial diagnosis methods for leishmaniasis: i) parasitological methods (detection of the parasite), ii) serological methods (detection of anti-Leishmania antibodies), iii) molecular methods (amplification of parasite DNA) and iv) assay of cell-mediated immunity. This last method not being widely applied to routine diagnosis and will not be discussed in the present report. It should be noted that, although there is a wide variety of diagnostic techniques for CVL, none of them offer $100 \%$ of sensitivity or specificity $[35,59]$.

In spite of serological techniques such as enzyme-linked immunosorbent assay (ELISA) and indirect immunofluorescence assay (IFAT) being the most widely used methods for the diagnosis of CVL [60] parasitological methods, such as direct examination of slides and isolation from tissue cultures, allow the parasite to be detected and can be used as confirmatory diagnostic methods for CVL [61]. In recent decades, molecular techniques such as polymerase chain reaction (PCR) have been introduced for the diagnosis of CVL, exhibiting high sensitivity and specificity [21]. These techniques detect the genetic material of the parasite, which can be used as confirmatory methods in cases of recently infected or asymptomatic animals, which tend not to be diagnosed serologically, and in most cases, do not show seroconversion, having a low parasite load $[4,60]$. In a study conducted in Belo Horizonte-MG, a VL-endemic area in Brazil, among 1,443 dogs evaluated, $15.3 \%$ of them were seropositive, while $84.7 \%$ showed negative serology. Interestingly, among serologically negative dogs, $24.4 \%$ showed up as positive using the molecular diagnostic technique, and most of these $(97.6 \%)$ would not be diagnosed, since they consist of asymptomatic dogs with negative serology [19].

\subsection{Clinical diagnosis}

Dogs from endemic areas considered resistant remain clinically normal and asymptomatic without exhibiting clinical signs. There is evidence that the parasites in these animals are effectively eliminated at the infection site $[62,63]$. However, in susceptible animals, a large number of parasites are detected in infected tissues. In these animals, the presence of the parasite may occur in multiple organs, accompanied by a granulomatous inflammatory reaction and production of immune-mediated phenomena, probably responsible for the appearance of various types of clinical signs [64].

Initial clinical signs of CVL include: hypertrophy of the lymph nodes, changes in skin appendages such as onychogryphosis, swelling of the footpad, localized alopecia, skin ulcers and nasal and periocular dermatitis. Alopecia and non-pruritic exfoliative dermatitis can spread to other parts of the animal's body. Weight loss may also be present, as well as cachexia, anorexia and conjunctivitis. Internal organs such as spleen, liver, kidney and lymph nodes may also be affected, when kidney injuries are present may lead to the dogs death [13, 65]. Fever, apathy, diarrhea, epistaxis, intestinal bleeding, hepatosplenomegaly, hyperkeratosis, keratoconjunctivitis are also found in affected animals [66-68]. Some clinical signs are more frequent than others; skin lesions are the most frequent manifestations affecting approximately 50 to $90 \%$ of symptomatic dogs $[4,67,69,70]$, including non-pruritic exfoliative dermatitis, with or without alopecia, which can be generalized or localized to the muzzle, ears and limbs $[67,71,72]$. Other very common signs are weight loss, observed in 25 to $80 \%$ of CVL cases, 
including onychogryphosis in 30 to $75 \%$, and ocular abnormalities in 16 to $24 \%$ [28]. The most common clinical signs of VL in dogs are depicted in Figure 1.
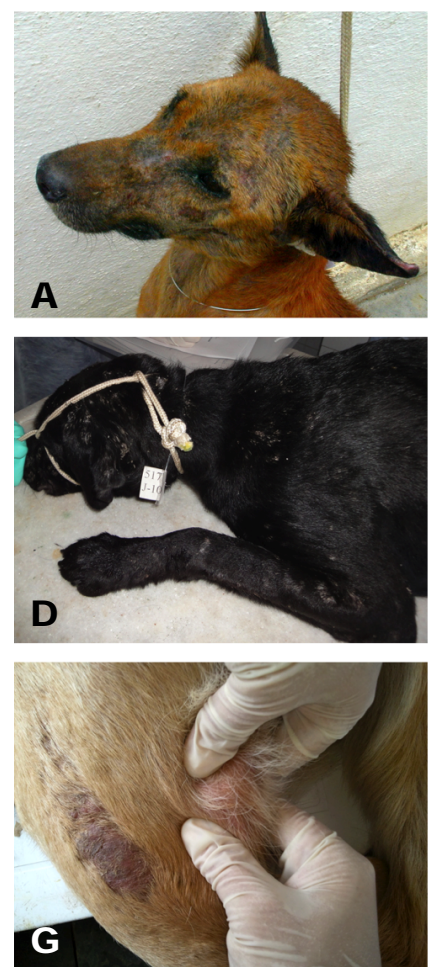
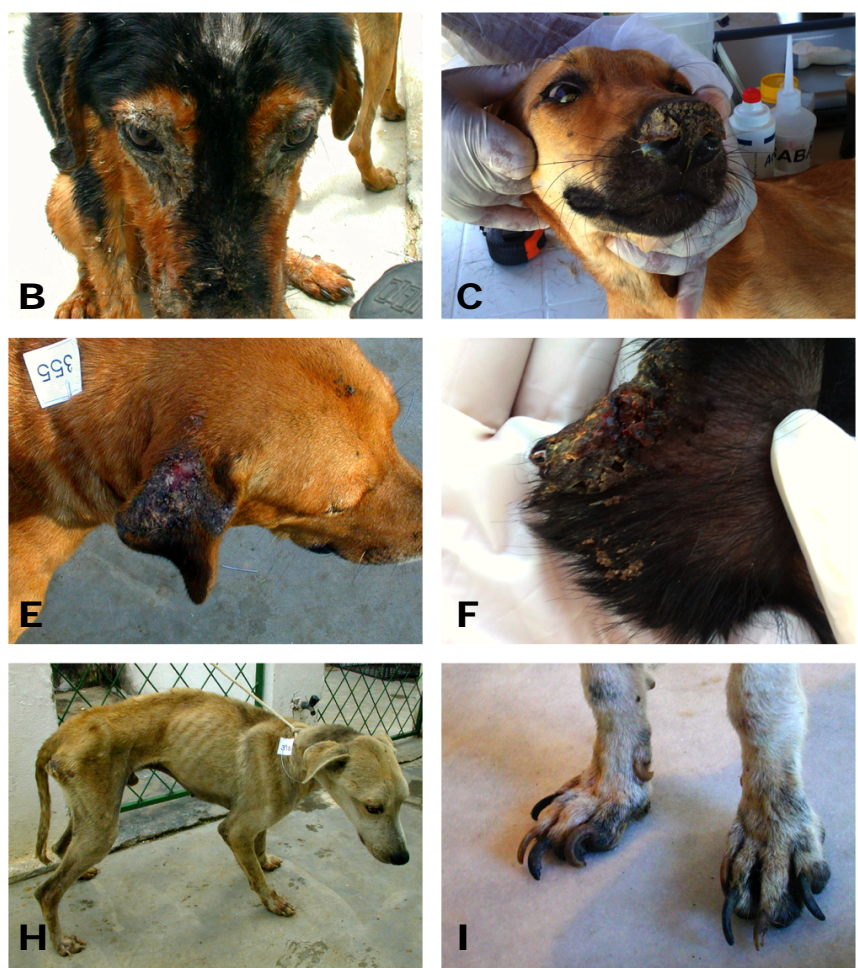

Figure 1. Major clinical signs associated with CVL. A: alopecia on the muzzle, B: periocular dermatitis with keratoconjunctivitis and hyperkeratosis; C: hyperkeratosis of the nasal mucosa; D: generalized non-pruritic exfoliative dermatitis; E: ulcerated lesion in the ear; F: crust with vascular injury on the tip of the ear; G: lymphadenomegaly of the popliteal lymph node; H: cachexia; I: onychogryphosis. Photos of animals infected by L. infantum belong to archives from Laboratory of Pathology and Biointervention(LPBI - CPqGM).

In dogs with CVL, clinical-pathological changes may occur such as intestinal lesions, renal and hepatic abnormalities [73]. The main biochemical laboratory findings from CVL are hyperglobulinemia, mainly due to increased production of antibodies, and hypoalbuminemia, attributed to chronic inflammation, as long as renal and hepatic failure [66]. The result of these changes is a reduction in the albumin/globulin ratio and hyperproteinemia [28]. Additionally, severe CVL is associated with changes in hematological parameters such as severe anemia and leukopenia, associated with lymphopenia, eosinopenia and monocytopenia [66, 74, 75]. 
Immune-mediated thrombocytopenia also occurs accounting for episodes of bleeding such as epistaxis, hematuria and hemorrhagic diarrhea [76].

Finally, nonspecific signs of illness that are mistaken for other diseases such as babesiosis, ehrlichiosis and canine trypanosomiasis also contribute to make CVL clinical diagnosis imprecise and difficult to perform [13].

\subsection{Parasitological diagnosis}

The detection by optical microscopy of the parasite by direct observation of stained smears from spleen aspirate, lymph node and bone marrow tissues has high specificity, allowing confirmation of CVL diagnosis [3, 53, 61, 77]. However, the sensitivity of this method is less than $30 \%$, since the direct parasite identification may be limited, especially in mildly and asymptomatic dogs that have low parasitic load, producing false negative results $[3,53,61,77]$.

Another method that can identify the parasite in tissues is the culturing of tissue fragments or aspirates, preferably in a biphasic medium [78], composed by Novy-MacNeal-Nicolle (NNN), or Tobie modified medium or United States Army Medical Research Units (USAMRU) as solid phase medium and, most often, Schneider as liquid phase medium. This parasitological diagnostic method offers high specificity allowing isolation and characterization of parasites, as well as determination of which species and/or variants are circulating in endemic areas [79]. However, the culturing consists of an indirect test, because when the parasites are isolated from various tissues, they are present in amastigote form and during cultivation they transform into the promastigote form. This process may be impaired as a result of parasite death due to a failure of temperature-control during transport of the tissue sample, or contamination during collection or cultivation [13]. Additionally, a culturing is time consuming and may take up to 4 weeks of observation for definitive diagnosis [13, 79]. Furthermore, specific media for promastigote isolation are not easily obtained, being a technique restricted to specialized laboratories [70, 80], in which the outcome also depends on the experience of the observer [24, 25]. Although culturing offers greater sensitivity compared to direct viewing of amastigotes in tissue [35], it still remains at very low levels.

In summary, parasitological techniques have high specificity but low sensitivity, especially for the detection of dogs, recently infected, asymptomatic or those presenting low parasite load. In addition, the need for skilled personnel and the long delays to obtain the results prevent parasitological techniques to be used in epidemiological surveys [4, 23, 61, 81-84].

\subsection{Serological diagnosis}

Serological tests are based on the presence of specific humoral immune responses against the pathogen or purified fraction or recombinant proteins of the pathogen. These tests allow detection of immunoglobulin (IgG) levels, thus becoming an essential tool for the diagnosis of CVL. These methods are simple to carry out and therefore they are frequently used to determine the prevalence of leishmaniasis in epidemiological studies [85]. 
A wide variety of serological methods are available for CVL diagnosis, presenting variations in sensitivity and specificity. The performance of these diagnostic techniques varies depending on the type of antigen used and the detection of anti-Leishmania antibody system.

The most commonly employed serological tests for the diagnosis of CVL, including ELISA, indirect immunofluorescence test (IFAT), and direct agglutination test (DAT), uses parasite or crude extract of Leishmania, as the antigen source. More recently, serological methods based on ELISA or rapid tests have been developed using a purified fraction of the parasite or a specific purified recombinant protein, such as rK39 or a chimeric protein as rK28 (rK9 + rK26 + rK39).

Despite the practicality and simplicity of serological tests, they do not have $100 \%$ sensitivity because some dogs, especially those that are resistant or in the early stages of the disease, have negative results. Thus, the results of such tests should be evaluated carefully, always associating test results with epidemiological history, clinical state of the animal, and the result of a more specific diagnostic test [86]. In addition, since titers of anti-Leishmania antibodies remain detectable for long periods, serological tests are not a good alternative for assessing healing or monitoring dogs after treatment [71].

\section{- IFAT}

IFAT is a test in which anti-immunoglobulin antibodies labeled with fluorochromes react with parasites immobilized in a slide. IFAT is a laborious technique that presents difficulties for both standardization and interpretation of the results Therefore, detection of antigen-antibody reaction by fluorescence microscopy depends on the observer experience, compromising reproducibility of this test in different laboratories. Thus, it is not considered a simple and practical technique for evaluating a large number of canine sera [57]. In spite of these limitations, it is still being used as a diagnostic method for mass screening of infected dogs [87]. This method varies in its performance, with sensitivity ranging from 68 to $100 \%$ and specificity of 60 to $90 \%$ [5, 88-90].

In a study evaluating IFAT for the diagnosis of CVL, the efficacy of the test was evaluated using 254 sera from infected and uninfected dogs and sera from animals with other parasitic diseases. The authors observed low sensitivity (72\%) and specificity (52\%), as well as crossreactions when sera from dogs infected with other pathologies, such as Trypanosoma cruzi, Leishmania braziliensis, and Ehrlichia canis were tested. In this study, the reproducibility of the results among different laboratories yielded a moderate rate of 0.74 [5]. A similar result was obtained by Lira et al. (2006) that using IFAT, found a low sensitivity and specificity of $68 \%$ and $87.5 \%$, respectively [88]. By contrast, it was shown by Alves and colleagues that the IFICVL kit, IFAT produced by Biomanguinhos (Brazil), provides high sensitivity (100\%), detecting all dogs with CVL, although presenting a low specificity of $70 \%$, levels similar to those observed in studies described above. This low level of specificity was due to false positive results from sera of dogs infected with Trypanosoma caninum (48.7\%) and healthy dogs (10.3\%) [90]. Thus, the Brazilian Ministry of Health withdrew the IFI-CVL kit from the CVL control program, due to data in literature that support IFAT has both low sensitivity, which led to 
maintenance of false-negative dogs in the endemic areas, and low specificity, which promoted the culling of false-positive dogs [65, 91, 92].

\section{- DAT}

The direct agglutination test (DAT) is an alternative method for the diagnosis of VL, first described in 1975 and adapted for the diagnosis of human and canine infection in the late 1980s $[93,94]$. DAT is a method that uses whole stained promastigotes as antigen, either in suspension or freeze-dried [35]. The advantage of this test lies in its low cost when compared with other tests [93]. However, this test is not desirable for screening large numbers of samples, since it is a laborious procedure, due to the production process for crude Leishmania antigen, as well as the need to perform serial dilutions of serum $[95,96]$. Regarding the accuracy of DAT, there is some controversy in the literature, the sensitivity appears relatively variable between 88 and $93 \%$ and specificity of 70 to $100 \%[5,59,96,97]$. It is likely that these variations are related to how the cutoff is defined, since cutoffs using smaller dilutions reduce sensitivity but raise the specificity, while those using higher dilutions increase sensitivity and reduce specificity [98].

Changes to the DAT protocol have been proposed by Gómez-Ochoa et al. (2003) in order to decrease the cost of the procedure and the preparation time of the antigen, while maintaining the same sensitivity and specificity of conventional DAT. One of the proposed changes for DAT protocol is the fast agglutination-screening test (FAST), which combines a higher concentration of parasites with a smaller test volume. FAST requires a single serum dilution and the results can be read in 3 hours $[95,96]$. However, in spite of the sensitivity of this technique being greater than that of conventional DAT, which varies from 93 to $98 \%$, the specificity values were similar to those from the conventional DAT, between $78-89 \%[95,96]$.

\section{- ELISA}

For various reasons, ELISA tests based on whole parasites or crude lysate of parasite antigens for the diagnosis of CVL do not provide satisfactory results, as follows: i) it is a laborious technique, which leads to a delay in the delivery of results and, consequently, the implementation of treatment or the removal of infected dogs from endemic areas [68, 99]; ii) leads to the appearance of cross-reactions with sera from individuals infected with other Leishmania species or even with a variety of other pathogens such as Toxoplasma gondii, Ehrlichia canis [23, 24, 29, 100-103], and parasites of the Trypanosomatidae family such as Trypanosoma cruzi [5, 29] or Trypanosoma caninum [90] iii) there are reports of low reproducibility between batches of ELISA based on whole parasites or crude antigens, since different isolates of Leishmania sp. were used and depending on the culturing batch, distinct antigenic compositions can be detected [104].

A study using 234 domesticated dogs in an endemic area for CVL assessed the efficacy of ELISA, IFAT and DAT for the diagnosis of CVL. In this study, dogs were also parasitologically evaluated for identification of Leishmania amastigotes in both skin samples and bone marrow aspirates. The sensitivity of IFAT was $72 \%$ and ELISA was $95 \%$. When the tests were evaluated 
against sera from dogs infected with other pathogens, T. cruzi, E. canis and L. braziliensis, the specificity of these tests shown to be very low $52 \%$ for IFAT and $64 \%$ for ELISA [5].

Using sera from dogs with CVL, a comparison of an ELISA test using crude soluble antigen of L. infantum (SLA) and another ELISA test based on ribosomal protein of L. infantum (LRP) was made. The sensitivity of the two tests was similar when evaluated against sera from symptomatic animals (100\%), but the ELISA based on LRP showed also higher sensitivity, reaching $100 \%$ in the detection of asymptomatic dogs, when compared with ELISA using SLA (19\%). Additionally, the LRP-based ELISA showed high specificity (98\%), with no cross-reactivity with sera from dogs with other diseases [102].

Thus, the search for tests with higher sensitivity and specificity for dogs with a variety of conditions became necessary for control of CVL, which would lead to a reduction of errors in actions taken for treatment or control. In countries that adopt culling of seropositive dogs as a control measure, low sensitivity of diagnostic tests can lead to the maintenance of dogs that transmit disease and lack of specificity can result in unnecessary culling of healthy dogs. The identification of new proteins of Leishmania sp. in order to compose diagnostic tests for CVL can improve both sensitivity and specificity of diagnostic techniques and allow infected dogs to be differentiated from the uninfected ones $[5,29,87,105,106]$.

Another way to overcome the obstacles of ELISA based on whole parasites or crude parasite antigen was the development of ELISA tests based on parasite fractions such as that using the parasite surface molecule, fucose-mannose ligand antigen (FML). The FML-based ELISA showed a high sensitivity, which was similar in detecting either oligosymptomatic $(90 \%)$ or symptomatic (90\%) dogs. Regarding specificity, ELISA using crude parasite antigen for the diagnosis of oligosymptomatic dogs was superior, achieving 100\% in comparison to FMLbased ELISA that was $93.3 \%$. However, for symptomatic dogs the specificity of the FML-based ELISA showed similar results of $96.7 \%$ compared to that obtained by ELISA based on crude parasite antigen (93.3\%) [101].

Other ELISA assays based on recombinant antigens such as rA2 from L. donovani, rK26 or rK39 from $L$. infantum have been developed. When compared to an ELISA test based on crude antigen, taking IFAT as the gold standard, and tested against sera from symptomatic dogs, sensitivities was higher for ELISA based on rK26 or rK39 from L. infantum, respectively, of 94\% and $100 \%$ in comparison to $88 \%$ for ELISA based on crude antigen and $70 \%$ for ELISA based on $\mathrm{rA} 2$ from L. donovani. However, ELISA based on rA2 showed the highest specificity value of $96 \%$ in comparison to those from ELISA based on crude parasite antigen or parasite recombinant antigens rK26, rK39, that showed values of, respectively, 87\%, 90\%, and 85\% [29]. Although good enough for diagnosis of symptomatic dogs, the use of ELISA tests based on recombinant antigens for the diagnosis of asymptomatic dogs seems to be disadvantageous. ELISA based on rA2 gave the lowest sensitivity of 30\%, followed by rK26 and rK39 that sensitivity yielded greater, but still stayed low with value of $66 \%$ for both tests, in comparison to the sensitivity of $88 \%$ for ELISA based on crude parasite antigen. By contrast, another in a multicenter study conducted in 5 regions of Italy using IFAT as gold standard, ELISA based on the recombinant antigen rK39 gave higher levels of sensitivity and specificity of $97.1 \%$ and 
$98.8 \%$, respectively [107]. It is possible that the differences found in relation to the performance of the ELISA containing these proteins may be related to the study design, characterization of serum samples and the experimental protocols of the ELISA assays.

Interestingly, the association of the recombinant proteins enhanced test performance both for detection of symptomatic and asymptomatic infected dogs. Indeed, using IFAT as the gold standard, ELISA based on the mix of rK9, rK26 and rK39 from L. donovani showed sensitivity of $95-100 \%$ and specificity of $100 \%$ against a panel of serum from parasitologically positive dogs, using parasitologically and serologically negative dogs as controls [108]. Furthermore, ELISA containing a chimeric protein rK28, containing reactive epitopes of the three recombinant proteins described above (rK9, rK26 and rK29), shown to present high levels of sensitivity and specificity of $99 \%$ and $96 \%$, respectively when tested against a panel of serum from dogs parasitologically positive or serologically positive using IFA, and sera from parasitologically negative dogs as controls [87]. In this study, the authors didn't evaluate rK28-based ELISA against sera from asymptomatic dogs.

The combination of these findings reinforces the notion that the use of multiple antigens in diagnostic tests enhances test performance and the need to search for new antigens that may compose a diagnostic test able to better diagnose asymptomatic dogs.

New recombinant proteins are being evaluated. Faria et al. (2011) performed predictions on Bcell epitopes, identifying 360 peptides that were synthesized onto nitrocellulose membranes [105]. The 10 most reactive were evaluated in an ELISA platform. The sensitivity and specificity of the ELISA based on these peptides varied from $70.96 \%$ to $88.7 \%$ and $55 \%$ to $95.0 \%$, respectively, a better result than that obtained with EIE-CVL kit, which gave a sensitivity of $13.8 \%$ and specificity of $100 \%$.

Another study evaluated the performance of the ELISA based on another recombinant antigens of L. infantum, rLci1A and rLci2B, against a panel of canine sera $(\mathrm{n}=256)$. ELISA based on rLci1A gave sensitivity of $96 \%$ and specificity of $92 \%$ for rLci1A and sensitivity of $100 \%$ and specificity of $95 \%$ for rLci2B. The recombinant antigens showed no cross-reactivity with sera from dogs infected with Trypanosoma caninum, Babesia canis and Ehrlichia canis. Cross-reaction against sera from dogs infected with Leishmania braziliensis was observed for rLci1A-based ELISA (11.7\%) and for rLci2B-based ELISA (2.9\%) [109].

In summary, most studies using ELISA suggest that in comparison to tests based on crude antigen, those based on recombinant antigens improves accuracy, increasing sensitivity and specificity for the diagnosis of symptomatic dogs. Although improved, test accuracy is still low for the detection of asymptomatic animals.

\section{- Rapid tests}

Recently, rapid immunodiagnostic tests have begun to be employed as routine laboratory tests for detection of diseases such as leishmaniasis. The recombinant antigens of the parasite are impregnated onto nitrocellulose membranes and serum samples are applied in the rapid test platform. Antigens impregnated in nitrocellulose membranes are recognized by specific immunoglobulin present in the serum of infected individuals. This reaction is revealed by 
the interaction of protein A coupled to colloidal gold particles, with the Fc portion of the immunoglobulins associated with the recombinant antigens. The use of immunochromatographic assays as diagnostic methods has the main advantages of being rapid, completed in around 15 minutes, easy to carry out and can dispense with the need for equipment to read the results [110]. Furthermore, these tests are easily stored, and test supplies and samples do not need to be maintained at low temperatures and can it even be performed at the place of collection. These tests are already widely used to detect HIV [111] and H1N1 [112] infection. For the diagnosis of CVL and human VL, among the tested and commercially available recombinant proteins, the most widely used for composing immunochromatographic tests is the recombinant protein rK39. This protein contains repetitive sequences of 39 amino acids from a protein related to kinesin of kinetoplast from L. infantum, and has been widely used in ELISA platform as described above [30, 31, 91, 96, 97, 110, 113-119].The efficacy of rK39-based rapid lateral flow test was compared with the IFAT against sera of parasitologically positive dogs from Italy. Both tests offered similar sensitivities of $97 \%$ for the lateral flow test in the dipstick format and $99 \%$ for the DAT, as well as the maximum specificity of $100 \%$ in both tests [120]. Similar results were obtained in other study which detected sensitivity of $97 \%$ and specificity of $100 \%$ using the rK39 dipstick for diagnosis of $\mathrm{CVL}$, indicating that the rK39 dipstick is promising for both large-scale screening in endemic areas and for veterinary clinical practice [121]. However, other studies also conducted in endemic areas for CVL showed that the dipstick based on the recombinant protein rK39 offered inferior performance to that of the studies described above, with sensitivity values of $61-75 \%$ and specificity of $72-84.9 \%[122,123]$. These differences in performance between these studies using dipsticks tests based on rK39 may be related to the use of sera from dogs with different conditions and therefore with varying concentrations of specific immunoglobulins [29-31, 118, 122]. Effectively, another study employing the rapid test based on the recombinant protein rK39 dipstick offered a sensitivity of $96.7 \%$ for sera from symptomatic dogs, compared to a sensitivity of $52.9 \%$ when evaluating sera from asymptomatic dogs [119]. Similarly, another study found that using sera from asymptomatic dogs that the sensitivity of the dipstick based on rK39 was $75 \%$ compared to sensitivities of $88 \%$ and $84 \%$ for sera from oligosymptomatic and polisymptomatic dogs, respectively [118]. In the same study, an ELISA based on crude parasite antigens yielded a sensitivity of $94 \%$ tested using sera from asymptomatic and oligosymptomatic and 95\% using sera of polisymptomatic dogs.

Recently, a meta-analysis was performed in order to broadly assess the performance of rapid tests using rK39 as the antigen in the diagnosis of CVL. The combined analysis of 16 studies using rapid tests based on rK39 offered a sensitivity of $86.7 \%$ (95\% CI: 76.9-92.8\%) for the detection of clinical disease and 59.3\% (95\% CI: 37.9-77.6\%) for identification of Leishmania infection with a specificity of $98.7 \%$ (95\% CI: 89.5-99.9\%). In summary, this study supports the idea that the rapid test based on rK39 is useful to confirm the disease in dogs with clinical suspicion. However, given its low sensitivity for the diagnosis of asymptomatic dogs, its use is not recommended for large-scale epidemiological studies or VL control programs [30]. 


\begin{tabular}{|c|c|c|c|c|c|c|c|}
\hline \multirow[b]{2}{*}{ 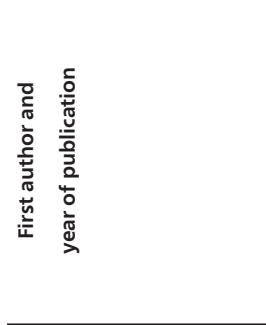 } & \multicolumn{2}{|c|}{ Serology } & \multicolumn{3}{|c|}{ Sample } & \multicolumn{2}{|c|}{ Results } \\
\hline & 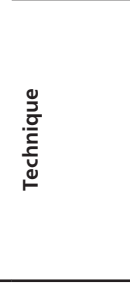 & 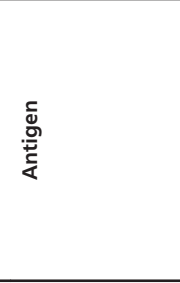 & 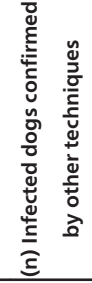 & 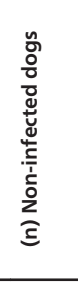 & 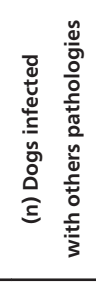 & 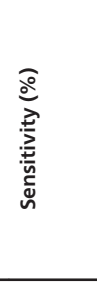 & 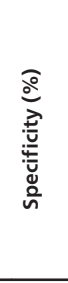 \\
\hline Harith et al., 1989 & DAT & $\begin{array}{l}\text { L. infantum } \\
\text { promastigotes }\end{array}$ & 44 & 6 & 176 & 98.9 & 100 \\
\hline $\begin{array}{l}\text { Barbosa-de-Deus et al., } \\
2002\end{array}$ & ELISA & LMS & 188 & 1582 & 55 & 98.0 & 95.0 \\
\hline Scalone et al., 2002 & ELISA & K39 & 209 & 81 & 62 & 97.1 & 98.8 \\
\hline \multirow[t]{2}{*}{ Schallig et al., 2002} & DAT & $\begin{array}{l}\text { L. donovani } \\
\text { promastigotes }\end{array}$ & 79 & 67 & 24 & 88.6 & 96.7 \\
\hline & FAST & $\begin{array}{l}\text { L. donovani } \\
\text { promastigotes }\end{array}$ & 79 & 67 & 24 & 93.6 & 89.0 \\
\hline \multirow[t]{3}{*}{ Rosati et al., 2003} & ELISA & $\mathrm{K} 26$ & 202 & 20 & 0 & 100 & 100 \\
\hline & ELISA & K9 & 202 & 20 & 0 & 95 & 95 \\
\hline & ELISA & K39 & 202 & 20 & 0 & 95 & 95 \\
\hline Mohebali, et al., 2004 & Dipstick & rK39 & $268^{*}$ & 0 & 0 & 70.9 & 84.9 \\
\hline Boarino et al., 2005 & ELISA & $\begin{array}{l}\text { K9-K39-K26 } \\
\text { chimera }\end{array}$ & 232 & 362 & 0 & 95.8 & 99.1 \\
\hline \multirow[t]{2}{*}{ Mettler et al., 2005} & Rapid test & rK39 & 47 & 50 & 26 & $\begin{array}{l}\text { A: } 52.9 \\
\text { S: } 96.7\end{array}$ & 94 \\
\hline & IFAT & $\begin{array}{l}\text { L. infantum } \\
\text { promastigotes }\end{array}$ & 47 & 50 & 26 & $\begin{array}{l}\text { A: } 29.4 \\
\text { S: } 90.0\end{array}$ & 100 \\
\hline \multirow[t]{2}{*}{ Lira et al., 2006} & $E I E^{*}-$ LVC & L. major lysate & 25 & 16 & 11 & 72.0 & 87.5 \\
\hline & $|F|^{\circ}-$ LVC & $\begin{array}{l}\text { L. major like } \\
\text { promastigotes }\end{array}$ & 25 & 16 & 11 & 68.0 & 87.5 \\
\hline \multirow[t]{3}{*}{ Ferreira et al., 2007} & $E I E^{*}-$ LVC & L. major lysate & $234^{*}$ & 20 & 20 & 96.0 & 100 \\
\hline & $|F|^{\circ}-$ LVC & $\begin{array}{l}\text { L. major like } \\
\text { promastigotes }\end{array}$ & $234^{*}$ & 20 & 20 & 72.0 & 100 \\
\hline & DAT & $\begin{array}{l}\text { L. donovani } \\
\text { promastigotes }\end{array}$ & $234^{*}$ & 20 & 20 & 93.0 & 100 \\
\hline Ferroglio et al., 2007 & $\mathrm{SNAP}^{\circ} \mathrm{CLA}$ & CTA & 59 & 124 & 0 & 91.1 & 99.0 \\
\hline Porrozzi et al., 2007 & ELISA & rK26 & 100 & 25 & 14 & $\begin{array}{l}\text { A: } 66.0 \\
\text { S: } 94.0\end{array}$ & 90.0 \\
\hline
\end{tabular}




\begin{tabular}{|c|c|c|c|c|c|c|c|}
\hline \multirow{8}{*}{ 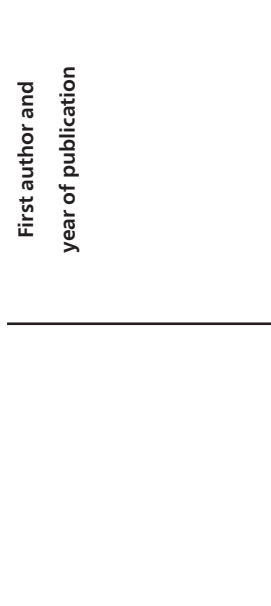 } & \multicolumn{2}{|c|}{ Serology } & \multicolumn{3}{|c|}{ Sample } & \multicolumn{2}{|c|}{ Results } \\
\hline & 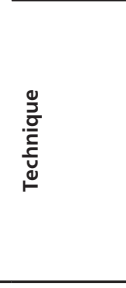 & 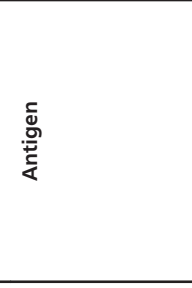 & 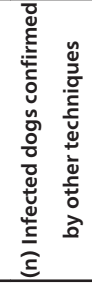 & 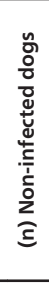 & 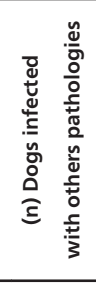 & 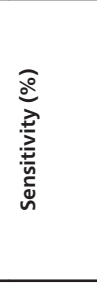 & 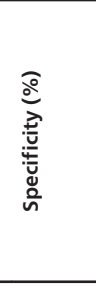 \\
\hline & ELISA & rK39 & 100 & 25 & 14 & A: 66.0 & 85.0 \\
\hline & & & & & & S: 100 & \\
\hline & ELISA & rA2 & 100 & 25 & 14 & A: 88.0 & 96.0 \\
\hline & & & & & & S: 70.0 & \\
\hline & ELISA & CTA & 100 & 25 & 14 & A: 30.0 & 87.0 \\
\hline & & & & & & S: 88.0 & \\
\hline \multirow[t]{4}{*}{ Cândido et al., 2008} & ELISA & CTA & 60 & 30 & 0 & O: 86.7 & O: 100 \\
\hline & & & & & & P: 90.0 & P: 93.3 \\
\hline & ELISA & FML & 60 & 30 & 0 & O: 90.0 & O: 93.3 \\
\hline & & & & & & $P: 86.7$ & P: 96.7 \\
\hline \multirow[t]{2}{*}{ Lemos et al., 2008} & RDTs & rK39 & 76 & 33 & 0 & 83 & 100 \\
\hline & ELISA & L. chagasi lysate & 76 & 33 & 0 & 95 & 100 \\
\hline Babakhan et al., 2009 & FAST & $\begin{array}{l}\text { L. infantum } \\
\text { promastigotes }\end{array}$ & 73 & 74 & 0 & 98.6 & 78.7 \\
\hline \multirow[t]{2}{*}{ Coelho et al., 2009} & ELISA & LRP & 111 & 47 & 14 & 100 & 98.2 \\
\hline & ELISA & CTA & 111 & 47 & 14 & 96.0 & 100 \\
\hline Troncarelli et al., 2009 & IFAT & $\begin{array}{l}\text { L. major like } \\
\text { promastigotes }\end{array}$ & 51 & 0 & 0 & 83.0 & 92.5 \\
\hline \multirow[t]{2}{*}{ Figueiredo et al., 2010} & $\mathrm{EIE}^{*}-\mathrm{LVC}$ & L. major lysate & $305^{\star}$ & 0 & 0 & 100 & 96.6 \\
\hline & $|F|^{\circ}-$ LVC & $\begin{array}{l}\text { L. major like } \\
\text { promastigotes }\end{array}$ & $305^{\star}$ & 0 & 0 & 22.2 & 97.0 \\
\hline \multirow[t]{2}{*}{ de Lima et al., 2010} & ELISA & CTA & 52 & 52 & 0 & 91.5 & 94.7 \\
\hline & RDTs & rK39 & 52 & 52 & 0 & 100 & 91.2 \\
\hline Marcondes et al., 2011 & SNAP $^{\circ}$ CLA & KCTA & 283 & 86 & 31 & 94.7 & 90.6 \\
\hline \multirow[t]{4}{*}{ Alves et al., 2012} & $E E^{*}-\operatorname{LVC}$ & L. major lysate & 39 & 39 & 39 & 100 & 68.0 \\
\hline & ELISA & L. chagasi lysate & 39 & 39 & 39 & 100 & 93.6 \\
\hline & $|F|^{\circ}-$ LVC & $\begin{array}{l}\text { L. major like } \\
\text { promastigotes }\end{array}$ & 39 & 39 & 39 & 100 & 70.5 \\
\hline & IFAT & L. chagasi lysate & 39 & 39 & 39 & 100 & 61.5 \\
\hline
\end{tabular}




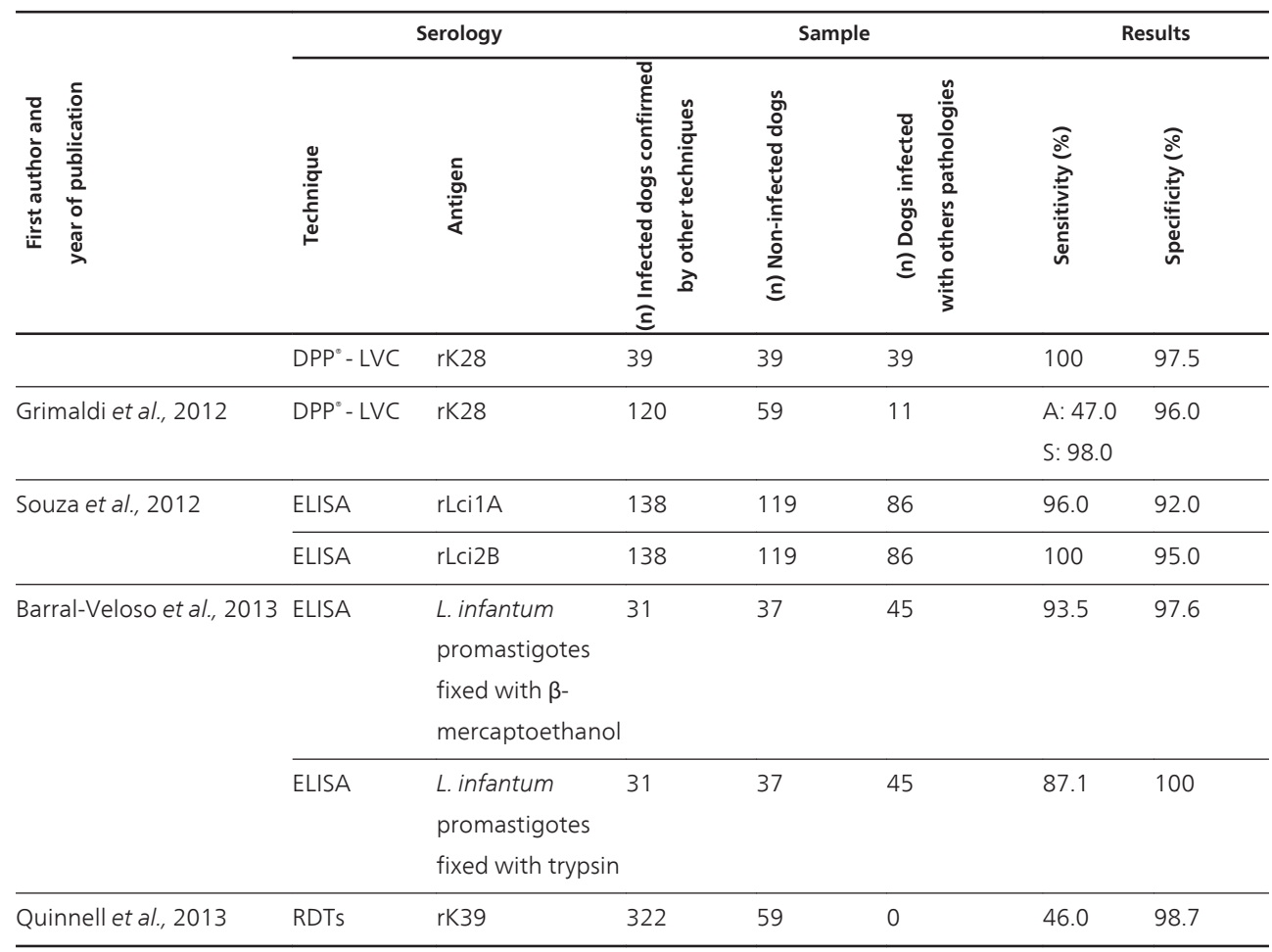

* Dogs from an endemic area for CVL without confirmed diagnosis.

A: asymptomatic dogs; S: dogs with clinical signs related to CVL; O: oligosymptomatic dogs (presenting one to three clinical signs of $C V L$ ); P: polysymptomatic dogs (presenting more than three clinical signs of CVL).

RDTs = Kalazar Detect - Canine Rapid Test

LMS $=$ L. major like promastigotes lysate

CTA = Crude Total Antigen - antigenic fractions of $L$. infantum promastigotes form

$\mathrm{FML}=$ Fucose-Mannose Ligand antigen - glycoprotein complex isolated from the surface of $L$. donovani

LRP = Leishmania species ribosomal proteins

Table 1. Sensitivity and specificity of some serological techniques by type of antigen, and evaluated population

Efforts have been made to improve the efficacy of rapid tests by developing more sensitive and specific method that could be used in mass screening for the diagnosis of CVL. An alternative proposal is to use a mixture of recombinant proteins or chimeric proteins. The protein rK28 chimeric for the relevant epitopes of three antigens, rK9, rK26 and rK39 [87, 108] that showed promising efficient results in an ELISA based test [124], was recently used to compose a new rapid test in DPP format. This format consists of a double track platform that offers greater sensitivity and specificity [125]. In addition, this rapid test has advantages over previously used serological methods due to greater precision, simplified interpretation of the 
data, minimal use of sample volumes, and compatibility with different types of body fluids such as blood, serum, saliva, plasma and urine. In contrast to these advantages, recently Grimaldi et al (2012) showed that rK28-based DPP despite its high sensitivity (98\%) and specificity (96\%) towards sera from symptomatic dogs, showed low sensitivity of only $47 \%$ towards sera from dogs with no signs [31]. With regard to sera from dogs with other diseases, the observed specificity was $96 \%$, with false-positive reactions mainly for some sera of dogs infected with L. braziliensis. Thus, L. infantum may not be detected in serological investigations of asymptomatic infected dogs, leading for perpetuation of the parasite cycle and, consequently, hampering the efficacy of the disease control measures. This limitation is reason for concern because several studies indicate that asymptomatic dogs are involved in transmission of infection to the vector, although this occurs less frequently than with symptomatic dogs [16, 32-34]. Therefore, it is necessary to implement more effective serodiagnostic tests so that there is broader detection of animals infected with $L$. infantum by public health services, contributing to more efficient control of CVL.

\subsection{PCR}

In recent decades, due to advances in molecular biology techniques and reduced implementation costs, the polymerase chain reaction (PCR) began to be used in VL diagnosis [23, 126]. Its use has demonstrated superior results to those obtained by ELISA, IFA and culture in detecting animals infected with Leishmania sp., exhibiting high sensitivity and specificity [23, 126].

PCR is a technique based on the principle of complementary bases pairing of the DNA molecule, allowing amplification and detection of a particular region of the target genome using a pair of specific oligonucleotide primers. The reaction can produce tens of billions of DNA fragments from a single molecule, and has high sensitivity small quantities of samples to be used. This type of PCR, hereafter referred as "conventional PCR" (cPCR) needs electrophoresis in agarose or polyacrylamide gels along with dyes such as ethidium bromide, SYBR Green or silver nitrate to view the amplified product. This approach is usually qualitative, with analysis of the presence or absence of bands, or semi-quantitative, when densitometry of bands is used in comparison with known standards. Since it uses qualitative or semi-quantitative analysis, it is imprecise and generates false negatives with some frequency.

A variant of cPCR called "quantitative real-time PCR" (qPCR) became popular in the 2000s. It uses a quantitative approach that allows real-time monitoring of the amplification of the target PCR fragment using fluorophores that bind to double stranded DNA or linked to probes. The most commonly used method is SYBR Green: fluorophore binds to double stranded DNA molecules produced during amplification of the target fragment, leading to the emission of fluorescence during the PCR. This method has the disadvantage of not being able to directly discriminate the amplification of nonspecific DNA fragments, which is usually solved by analyzing the dissociation curve. In contrast, the TaqMan method uses a probe containing between 13 and 30 nucleotides, specifically for the target sequence and combined with a fluorophore and a fluorescence inhibitor. During polymerization of the target fragment, DNA 
polymerase degrades the probe and fluorescence is emitted. The use of this technique enables an increase in the specificity of this method.

Various PCR-based protocols have been developed for the detection of parasite's DNA and CVL diagnosis. However, the methods used may vary with respect to several parameters, such as fluorophores, probes, target regions and tissue used for detection of target DNA (Table 2), making it difficult to do a comparative analysis between the different protocols. It is known that the sensitivity and specificity of PCR for detection of Leishmania sp. depends on many factors such as the physico-chemical conditions of the reaction, the concentration and nature of the sample DNA, the probes, and oligonucleotide primers selected for the target region [44, $127,128]$. The protocols standardization based on changes in previous parameters is the key step to increased sensitivity, specificity and reproducibility of the tests.

The PCR protocol sensitivity is also affected by the type of tissue used in the detection of Leishmania sp. DNA. A wide variety of clinical samples can be used such as blood, lymph node, bone marrow, conjunctiva, skin and spleen. The sensitivity tends to vary, since the parasitic load is not equally distributed in all tissues [4, 7, 129-133]. However, studies have shown that PCR can detect the presence of Leishmania DNA in a similar way, even in different tissues as demonstrated by Manna et al. (2004) in a study using 56 dogs naturally infected with $L$. infantum, which evaluated samples from lymph nodes, skin and blood by cPCR obtaining positivity values of $99 \%, 95 \%$ and $94 \%$ respectively [133]. Similarly, Ferreira et al. (2013), using qPCR, obtained positivity values on the order of $90 \%$ for blood samples, $97 \%$ for skin biopsy, $98 \%$ for conjunctival swab samples and $100 \%$ for bone marrow samples [134]. Other studies showed better results for sensitivity to certain tissue, such as Maya et al. (2009) that evaluated dogs with different clinical profiles and demonstrated that the use of cPCR for parasite DNA detection on lymph node aspirate would be ideal for the early CVL diagnosis in symptomatic animals [132], a finding later corroborated by Lombardo et al. (2012) and Belinchon-Lorenzo (2013) $[135,136]$. However, in the absence of lymphadenopathy, other studies showed that bone marrow aspirates offered better sensitivity, since it has a higher parasite load in relation to lymph nodes $[132,137]$. Studies indicate bone marrow as the tissue in which PCR has greater sensitivity; as reported by Andrade et al. (2002), where bone marrow aspirate gave a sensitivity of $100 \%$ [138]. However Ferreira et al (2008) obtained positivity values of only 50\% for bone marrow aspirates from asymptomatic and 77\% from symptomatic dogs using cPCR followed by hybridization, using cloned kDNA-probes from mini circles of L. infantum [139].

The selection of target region in the parasite genome is important because the variation in the number of copies, depending on the region, influences the sensitivity for detecting the parasite's DNA and for quantification of parasite load. The highly conserved and repetitive regions are the most commonly employed, such as the gene for subunit ribosomal RNA (rRNA) or minicircle kinetoplast DNA (kDNA) [21, 23, 127, 140, 141], that has 40-200 copies per cell, while the kDNA minicircles have about 10,000 copies distributed among 10 different classes of sequences. Using this as a target region confers high sensitivity to PCR [142]. For quantification of the parasitic load is recommended to normalize the amount of parasite gene amplification in relation to a constitutive gene derived from the host genome in order to correct distortions caused by errors in the DNA used in the PCR reaction [127]. 


\begin{tabular}{|c|c|c|c|c|c|c|c|c|c|}
\hline \multirow[b]{2}{*}{ 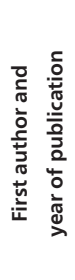 } & \multicolumn{2}{|c|}{ qPCR technique } & \multicolumn{3}{|c|}{ qPCR internal control } & & \multicolumn{2}{|l|}{ Sample } & Result \\
\hline & 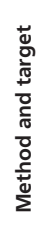 & 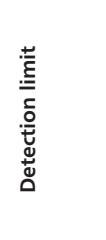 & & $\stackrel{\circ}{\stackrel{\varepsilon}{\xi}}$ & 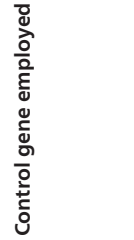 & છ & 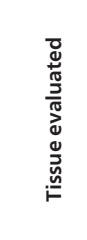 & 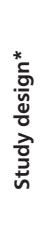 & \\
\hline
\end{tabular}

\begin{tabular}{|c|c|c|c|c|c|c|c|c|c|}
\hline $\begin{array}{l}\text { Ferreira et al. } \\
2012\end{array}$ & $\begin{array}{c}\text { Syber } \\
\text { a pol DNA }\end{array}$ & $\mathrm{NI}$ & Yes & Yes & B-canine actin & $\begin{array}{l}\text { (80) Infected } \\
\text { dogs }\end{array}$ & $\begin{array}{c}\text { Conjunctival } \\
\text { swab, blood, bone } \\
\text { marrow and skin }\end{array}$ & Comparative $\mathrm{e}^{1,2}$ & $\begin{array}{c}\text { Skin > Bone } \\
\text { marrow > } \\
\text { Conjunctival } \\
\text { swab > Blood }\end{array}$ \\
\hline $\begin{array}{l}\text { Solcà et al. } \\
\text { 2014" }\end{array}$ & $\begin{array}{l}\text { TaqMan } \\
\text { kDNA }\end{array}$ & $\begin{array}{c}0.01 \\
\text { parasites/ } \\
\text { reaction }\end{array}$ & Yes & Yes & $\begin{array}{c}\text { 18S eukaryotic } \\
\text { rRNA }\end{array}$ & (51) Dogs & $\begin{array}{l}\text { Bone marrow, } \\
\text { conjunctival swab, } \\
\text { lymph node, skin } \\
\text { and spleen }\end{array}$ & Comparative $\mathrm{e}^{1,2}$ & $\begin{array}{c}\text { Spleen }>\text { Blood } \\
>\text { Lymph node }> \\
\text { Skin }>\text { Bone } \\
\text { marrow > } \\
\text { Conjunctival } \\
\text { swab }\end{array}$ \\
\hline $\begin{array}{c}\text { Belinchón- } \\
\text { Lorenzo et al. } \\
2013\end{array}$ & $\begin{array}{l}\text { TaqMan } \\
\text { kDNA }\end{array}$ & $\begin{array}{l}0.0079 \\
\text { parasites/ } \\
\text { reaction }\end{array}$ & Yes & Yes & $\begin{array}{c}\text { 185 eukaryotic } \\
\text { rRNA }\end{array}$ & (28) Dogs & $\begin{array}{l}\text { Blood, hair and } \\
\text { lymph node }\end{array}$ & Comparative $^{2}$ & $\begin{array}{c}\text { Lymph node > } \\
\text { Hair = Blood }\end{array}$ \\
\hline $\begin{array}{l}\text { Ferreira et al. } \\
2013\end{array}$ & $\begin{array}{c}\text { Syber } \\
\text { a pol DNA }\end{array}$ & $\mathrm{NI}$ & Yes & Yes & B-canine actin & $\begin{array}{c}\text { (62) CVL } \\
\text { positive dogs }\end{array}$ & $\begin{array}{c}\text { Conjunctival, } \\
\text { nasal and ear } \\
\text { swab, blood, Bone } \\
\text { marrow and skin }\end{array}$ & $\begin{array}{c}\text { Comparative } \\
1,2\end{array}$ & $\begin{array}{c}\text { Skin = Nasal } \\
\text { swab and bone } \\
\text { marrow > } \\
\text { Conjunctival } \\
\text { swab > Oral } \\
\text { swab > Ear } \\
\text { swab }\end{array}$ \\
\hline $\begin{array}{c}\text { Geisweid et al. } \\
2013\end{array}$ & $\begin{array}{l}\text { Syber } \\
\text { kDNA }\end{array}$ & $\mathrm{NI}$ & Yes & No & Canine NCX1 & $\begin{array}{c}\text { (74) CVL } \\
\text { suspected dogs }\end{array}$ & $\begin{array}{l}\text { Conjunctival } \\
\text { swab, blood, bone } \\
\text { marrow and } \\
\text { lymph node }\end{array}$ & Comparative $^{2}$ & $\begin{array}{c}\text { Bone marrow > } \\
\text { Conjunctival } \\
\text { Swab }\end{array}$ \\
\hline Reis et al. 2013 & $\begin{array}{c}\text { Syber } \\
\text { a pol DNA }\end{array}$ & $\mathrm{NI}$ & Yes & No & G3PDH & $\begin{array}{l}(60) \\
\text { Seropositive } \\
\text { dogs }\end{array}$ & Skin and spleen & $\begin{array}{c}\text { Comparative } \\
1,2\end{array}$ & Spleen > Skin \\
\hline $\begin{array}{c}\text { Pennisi et al. } \\
2005\end{array}$ & $\begin{array}{c}\mathrm{NI} \\
\mathrm{kDNA}\end{array}$ & $\mathrm{NI}$ & No & No & --- & (6) Treated dogs & $\begin{array}{l}\text { Blood, lymph } \\
\text { node and skin }\end{array}$ & Not comparative & --- \\
\hline $\begin{array}{c}\text { Francino et al. } \\
2006\end{array}$ & $\begin{array}{l}\text { TaqMan } \\
\text { kDNA }\end{array}$ & $\begin{array}{c}0.001 \\
\text { parasites/ } \\
\text { reaction }\end{array}$ & Yes & No & $\begin{array}{c}\text { 18S eukaryotic } \\
\text { rRNA }\end{array}$ & $\begin{array}{c}\text { (15) Dogs with } \\
\text { clinical signs } \\
\text { suggestive of } \\
\text { CVL }\end{array}$ & $\begin{array}{c}\text { Blood and bone } \\
\text { marrow }\end{array}$ & Comparative ${ }^{1,2}$ & $\begin{array}{c}\text { Bone marrow > } \\
\text { Blood }\end{array}$ \\
\hline $\begin{array}{c}\text { Rodriguez- } \\
\text { Cortez et al. } \\
2007\end{array}$ & $\begin{array}{l}\text { TaqMan } \\
\text { kDNA }\end{array}$ & $\begin{array}{c}0.001 \\
\text { parasites/ } \\
\text { reaction }\end{array}$ & Yes & Yes & $\begin{array}{c}\text { 185 eukaryotic } \\
\text { rRNA }\end{array}$ & $\begin{array}{l}\text { (6) } \\
\text { Experimentally } \\
\text { infected dogs }\end{array}$ & $\begin{array}{l}\text { Blood, bone } \\
\text { marrow, liver, } \\
\text { lymph node, skin } \\
\text { and spleen }\end{array}$ & Not comparative & --- \\
\hline $\begin{array}{c}\text { Solano-Gallego } \\
\text { et al. } 2007\end{array}$ & $\begin{array}{l}\text { Syber } \\
\text { kDNA }\end{array}$ & $\begin{array}{c}7 \\
\text { parasites } / \mathrm{ml}\end{array}$ & Yes & No & Canine GAPDH & $\begin{array}{c}(10) \\
\text { Symptomatic }\end{array}$ & $\begin{array}{l}\text { Blood, bone } \\
\text { marrow and urine }\end{array}$ & Comparative $^{2}$ & $\begin{array}{c}\text { Bone marrow > } \\
\text { Blood }\end{array}$ \\
\hline
\end{tabular}




\begin{tabular}{|c|c|c|c|c|c|c|c|c|c|}
\hline \multirow{3}{*}{ 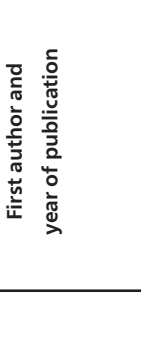 } & \multicolumn{2}{|c|}{ qPCR technique } & \multicolumn{3}{|c|}{ qPCR internal control } & \multicolumn{2}{|c|}{ Sample } & \multicolumn{2}{|c|}{ Results } \\
\hline & 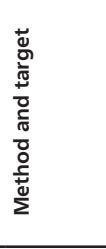 & 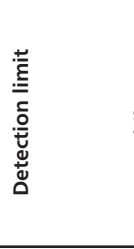 & فํ. & 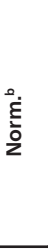 & 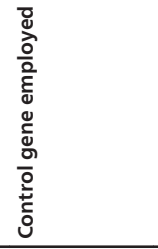 & છ & 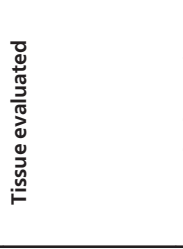 & 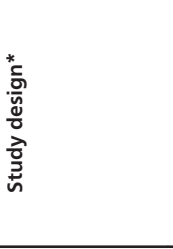 & : \\
\hline & & & & & & $\begin{array}{l}\text { dogs naturally } \\
\text { infected }\end{array}$ & & & > Urine \\
\hline $\begin{array}{c}\text { Manna et al. } \\
2008\end{array}$ & $\begin{array}{c}\text { TaqMan } \\
\text { kDNA }\end{array}$ & $\begin{array}{c}0.001 \\
\text { parasites } / \mathrm{ml}\end{array}$ & Yes & Yes & $B$ - actin & $\begin{array}{c}\text { (18) Naturally } \\
\text { infected treated } \\
\text { dogs }\end{array}$ & $\begin{array}{l}\text { Blood, lymph } \\
\text { node and skin }\end{array}$ & Comparative $^{2}$ & $\begin{array}{l}\text { Lymph node > } \\
\text { Skin > Blood }\end{array}$ \\
\hline $\begin{array}{c}\text { Manna et al. } \\
2009\end{array}$ & $\begin{array}{l}\text { TaqMan } \\
\text { kDNA }\end{array}$ & $\mathrm{NI}$ & Yes & Yes & B - actin & (56) Dogs & $\begin{array}{l}\text { Blood and lymph } \\
\text { node }\end{array}$ & Not comparative & --- \\
\hline $\begin{array}{c}\text { Quaresma et } \\
\text { al. } 2009\end{array}$ & $\begin{array}{l}\text { Syber } \\
\text { kDNA }\end{array}$ & $\begin{array}{c}0.1 \mathrm{pg} \\
\mathrm{DNA} / \mathrm{ml}\end{array}$ & Yes & Yes & $\begin{array}{l}\text { B-canine } \\
\text { globin }\end{array}$ & (35) Dogs & $\begin{array}{c}\text { Blood and bone } \\
\text { marrow }\end{array}$ & Comparative $^{2}$ & $\begin{array}{c}\text { Blood = Bone } \\
\text { marrow }\end{array}$ \\
\hline $\begin{array}{l}\text { Maia et al. } \\
2010\end{array}$ & $\begin{array}{l}\text { TaqMan } \\
\text { kDNA }\end{array}$ & $\begin{array}{l}1 \text { parasite / } \\
\text { reaction }\end{array}$ & Yes & No & B-canine actin & $\begin{array}{l}\text { (12) } \\
\text { Experimentally } \\
\text { infected dogs }\end{array}$ & $\begin{array}{l}\text { Blood, bone } \\
\text { marrow, buffy } \\
\text { coat, liver, lymph } \\
\text { node, skin and } \\
\text { spleen }\end{array}$ & Comparative $e^{1,2}$ & $\begin{array}{l}\text { Spleen / Buffy } \\
\text { coat / Liver / } \\
\text { Lymph node / } \\
\text { Bone marrow / } \\
\text { Skin > Blood }\end{array}$ \\
\hline $\begin{array}{l}\text { Galletti et al. } \\
2011\end{array}$ & $\begin{array}{c}\text { TaqMan } \\
\text { kDNA }\end{array}$ & $\begin{array}{c}0.03 \\
\text { parasite/ } \\
\text { reaction }\end{array}$ & No & No & --- & (88) Dogs & $\begin{array}{l}\text { Conjunctival } \\
\text { swab, Lymph } \\
\text { node, bone } \\
\text { marrow and } \\
\text { blood }\end{array}$ & Comparative $^{1}$ & --- \\
\hline $\begin{array}{c}\text { Lombardo et } \\
\text { al. } 2011\end{array}$ & $\begin{array}{c}\text { TaqMan } \\
\text { kDNA }\end{array}$ & $\mathrm{NI}$ & No & No & --- & (138) Dogs & $\begin{array}{l}\text { Blood, } \\
\text { conjunctival and } \\
\text { oral swabs and } \\
\text { lymph node }\end{array}$ & Comparative $^{1}$ & --- \\
\hline $\begin{array}{c}\text { Naranjo et al. } \\
2011\end{array}$ & $\begin{array}{l}\text { TaqMan } \\
\text { kDNA }\end{array}$ & $\mathrm{NI}$ & Yes & No & $\begin{array}{c}\text { 18S eukaryotic } \\
\text { rRNA }\end{array}$ & (22) Sick dogs & $\begin{array}{l}\text { Main lacrimal } \\
\text { gland, tarsal gland } \\
\text { and nictitating } \\
\text { membrane gland }\end{array}$ & Comparative ${ }^{1}$ & --- \\
\hline
\end{tabular}

* Study design: Comparative ${ }^{1}$ : aim to compare different diagnostic techniques results; Comparative: aim to compare different canine tissue sensitivity; ${ }^{* *}$ Sensitivity: evaluation of Leishmania sp. detection in the different canine tissues; $\mathrm{NI}$ : Not informed; \# submitted; a: qPCR inhibition control; b: qPCR normalization control.

Table 2. List of papers using the qPCR technique for Leishmania sp. detection in different canine tissues, comparing the different methodologies and the use of internal control of the reaction

In a cytological study, Reis et al. (2006) showed that the spleen is a major organ where parasite density is high throughout the course of CVL in both symptomatic and asymptomatic dogs [74]. Saldarriaga et al. (2006) demonstrated in a study using dogs submitted to intradermal experimental infection with promastigotes of Leishmania sp. ninety-six hours after inoculation, 
parasites were found in the lymph nodes and spleen of infected animals [148]. Another study revealed varying degrees of splenomegaly in most dogs infected with Leishmania sp. [132]. Reis et al. (2013) found $100 \%$ of positivity in spleen samples of 37 infected animals [149]. These findings make the spleen the best choice for the CVL diagnosis employing molecular techniques [150]. Nevertheless, obtaining spleen samples, even if tolerated by the animal, can incur a risk of hemorrhage and internal lesions [150]. However, in a study performed by BarrouinMelo et al. (2006) in which 257 splenic punctures were performed, only two animals had the intestinal loop aspirated and one animal experienced bleeding at the puncture site [151]. These risks can be minimized by organ visualization using ultrasound devices, which allow a guided and safe collection of tissue sample [152]. In a recent study performed by the present authors, 1,200 dogs were punctured with the aid of ultrasound machine without any incident (unpublished data).

Splenic collection, bone marrow and lymph node aspirates are considered invasive procedures [153] in addition to having an elevated cost compared to blood collection. Thus, it can be recommended to use samples obtained less invasively, such as blood and conjunctival swabs $[136,154,155]$. These samples are quick and easy to obtain, and it is low-cost compared to more invasive procedures, in addition to their higher acceptance by animal owners [132, 154, 155].

Some studies have shown that detection of parasites in the peripheral blood is less sensitive compared to other tissue samples such as spleen, bone marrow, lymph nodes and skin and tends to have variable parasitic load in accordance with the stage of infection $[129,141,156]$. However, depending on the technique and the target, blood can be used for detection of Leishmania sp. infection even when there is a low parasitic load [142, 157]. Maia et al. (2009) showed that the use of peripheral blood samples, extracted from soaked filter paper, from 29 infected dogs showed $93.1 \%$ positivity in CPCR of kDNA, suggesting that this tissue can be used as a complement for serological diagnosis [132]. However, despite blood has the advantage of being less invasive than spleen, bone marrow and lymph node punctures, this tissue contains hemoglobin that may acts as inhibitor to the PCR reaction, which are usually neutralized by the addition of albumin, and also present a high variability in parasite detection, due to the fluctuation of parasitemia according to the stage of infection.

According to Solano-Gallego et al. (2001) in comparison to other tissues, skin has the greatest sensitivity [4]. In a study involving 80 naturally infected dogs, Ferreira et al. (2012) showed that skin is the tissue with the higher parasitic load, showing no significant difference between symptomatic and asymptomatic animals [139]. Reis et al (2013) used skin samples from 37 animals and by means of qPCR obtained a sensitivity of $97.3 \%$ in identifying infected dogs. Nevertheless, other noninvasive samples are being tested for molecular diagnosis of CVL, such as conjunctival swabs [149]. Using this type of sample with cPCR, Ayali-Strauss et al (2004) were able to detect $92 \%$ of the symptomatic animals evaluated in the study, using spleen or lymph node aspirates, they detected $86 \%$ whereas using peripheral blood or white blood cells they detected, respectively, only $17 \%$ and $57 \%$ of the infected dogs [158]. Leite et al (2010) also succeeded in detecting the parasite DNA from conjunctival swabs of asymptomatic animals by the technique of CPCR followed by kDNA-probe hybridization [159]. Lombardo (2012) using qPCR technique with conjunctival swabs obtained similar results to those obtained with 
more invasive samples such as lymph node aspirates [136]. Ferreira et al. (2012) used cPCR followed by kDNA-probe hybridization of blood samples, skin, marrow and conjunctival swabs. The use of swabs gave the best results for detection of infection in both symptomatic and asymptomatic dogs, showing to be a suitable sample for the molecular diagnosis of CVL. Furthermore, Di Muccio et al (2012) argue that the use of nested PCR from conjunctival swabs shown to be the least invasive procedure with the best performance for the diagnosis of CVL in asymptomatic animals [156].

Among other less invasive sample types investigated, Solano-Gallego et al (2007) evaluated urine samples with qPCR technique, but the results described showed positivity only in dogs with severe renal injury [160]. Naranjo et al. (2012) identified the presence of Leishmania sp. DNA in lacrimal glands of infected dogs using $\mathrm{qPCR}$, with positive correlation between positivity and the presence of ocular lesions [161]. Recently, Belinchon-Lorenzo (2013), using qPCR, demonstrated the presence of Leishmania kDNA in the hair and keratinocytes of infected animals. According to the authors, the use of the non-invasive hair sample for the diagnosis of CVL would be advantageous because it is easy to collect, handle, transport, and store [135]. However, further studies should be conducted to determine the sensitivity of this method.

\begin{tabular}{|c|c|c|c|c|}
\hline \multirow[b]{2}{*}{ Laboratory - Country } & \multicolumn{4}{|c|}{ Tests Price } \\
\hline & Serology & CPCR & qPCR & $\begin{array}{l}\text { qPCR and } \\
\text { Citology }\end{array}$ \\
\hline Elleviti - Torino, Italy & $26.80^{\star}$ & --- & $63.00^{*}$ & --- \\
\hline Scanelis - Toulouse, France & --- & --- & $60.30^{*}$ & --- \\
\hline $\begin{array}{l}\text { Laboratoire d'Anatomie Pathologique Vétérinaire du Sud-Ouest - } \\
\text { Toulouse, France }\end{array}$ & --- & --- & --- & $127.30^{*}$ \\
\hline Laboratório Veterinário INNO - Braga, Portugal & $20.60^{\star}$ & $54.40^{*}$ & --- & --- \\
\hline $\begin{array}{l}\text { Instituto Nacional de Investigação Agrária e Veterinária, I.P. - } \\
\text { Lisbõa, Portugal }\end{array}$ & $28.00^{*}$ & $41.20^{*}$ & --- & --- \\
\hline Centro de Investigación y Análisis Biológicos - Madrid, Spain & $13.60^{\star}$ & $60.30^{*}$ & $73.70^{*}$ & --- \\
\hline $\begin{array}{l}\text { Texas Veterinary Medical Diagnostic Laboratory - San Antonio TX, } \\
\text { USA }\end{array}$ & 19.20 & --- & --- & --- \\
\hline Cornell University - Ithaca NY, USA & 22.50 & 60.00 & --- & --- \\
\hline Hermes Pardini - Belo Horizonte MG, Brazil & $17.20^{*}$ & $60.20^{\star}$ & --- & --- \\
\hline Análisis Biológicos- Chapecó SC, Brazil & $9.40^{*}$ & $42.15^{\star}$ & $72.25^{\star}$ & -- \\
\hline Laborlife - Rio de Janeiro RJ, Brazil & $30.10^{*}$ & $77.40^{*}$ & --- & --- \\
\hline
\end{tabular}

*Prices in Euros (€) and Brazilian Real (R\$) converted in US dollars (U\$), quotation of November 14th of 2013. €1=aprox. U\$ 1.34 - €1 = aprox.R\$ 0.43

Table 3. Cost of the main diagnostic test for CVL in different laboratories consulted in the second semester of 2013 in U\$ 
Despite the high sensitivity and specificity, the use of molecular methods for the CVL diagnosis presents some limitations to its use in epidemiological surveys: i) it has higher costs than other techniques (Table 3) used in the CVL diagnosis, including reagent and equipment costs; ii) it presents relative complexity in its implementation, requiring personnel with training in the execution of PCR reactions. However, this method has advantages in terms of sensitivity and specificity when compared to other diagnostic techniques, which justify its use in confirming cases screened by serology [24, 132]. Particularly due to the possibility of quantifying target DNA, qPCR may be used to monitor the parasitic load of the animal during the experimental infection, or during and after treatment in countries where it is permitted [35-37, 162]. Compared with $\mathrm{cPCR}$, qPCR enables a reduction in the probability of false positives resulting from amplification artifacts and greater speed in obtaining results, once electrophoresis is no longer performed [163].

\section{Conclusion}

In summary, detailed clinical evaluation complemented with highly sensitive test allows proper identification of infected dogs in an endemic area. Evidence shows that the use of a rapid serological test associated with a molecular diagnostic test with high specificity, such as qPCR, is required for identification of all infected dogs, both asymptomatic and symptomatic. On the other hand, for sick dogs a correct diagnosis is necessary either to perform dog culling in countries where this measure is used as a control strategy of VL or to define treatment. In this case, a detailed clinical evaluation should be associated with biochemistry and hematological tests to identify signs of renal and hepatic failure, in conjunction with a serological test to confirm animal clinical condition.

\section{Author details}

Patrícia Sampaio Tavares Veras ${ }^{1,2^{*}}$, Deborah Bittencourt Mothé Fraga ${ }^{1,2,3}$, Manuela da Silva Solcà ${ }^{1,3}$ and Carlos Eduardo Sampaio Guedes ${ }^{1}$

*Address all correspondence to: pveras@bahia.fiocruz.br

1 Laboratório de Patologia e Biointervenção, Centro de Pesquisa Gonçalo Moniz-FIOCRUZ, Salvador, Bahia, Brazil

2 Instituto Nacional de Ciência e Tecnologia em Doenças Tropicais (INCT - DT), Salvador, Bahia, Brazil

3 Escola de Medicina Veterinária e Zootecnia, Universidade Federal da Bahia, Salvador, Bahia, Brazil 


\section{References}

[1] Desjeux P. Leishmaniasis. Nat Rev Microbiol. 2004;2(9):692.

[2] Alvar J, Velez ID, Bern C, Herrero M, Desjeux P, Cano J, et al. Leishmaniasis worldwide and global estimates of its incidence. PLoS One. 2012;7(5):e35671.

[3] Gomes YM, Paiva Cavalcanti M, Lira RA, Abath FG, Alves LC. Diagnosis of canine visceral leishmaniasis: biotechnological advances. Vet J. 2008;175(1):45-52.

[4] Solano-Gallego L, Morell P, Arboix M, Alberola J, Ferrer L. Prevalence of Leishmania infantum infection in dogs living in an area of canine leishmaniasis endemicity using PCR on several tissues and serology. J Clin Microbiol. 2001;39(2):560-3.

[5] Ferreira Ede C, de Lana M, Carneiro M, Reis AB, Paes DV, da Silva ES, et al. Comparison of serological assays for the diagnosis of canine visceral leishmaniasis in animals presenting different clinical manifestations. Vet Parasitol. 2007;146(3-4):235-41.

[6] Troncarelli MZ, Camargo JB, Machado JG, Lucheis SB, Langoni H. Leishmania spp. and/or Trypanosoma cruzi diagnosis in dogs from endemic and nonendemic areas for canine visceral leishmaniasis. Vet Parasitol. 2009;164(2-4):118-23.

[7] Solca Mda S, Guedes CE, Nascimento EG, Oliveira GG, dos Santos WL, Fraga DB, et al. Qualitative and quantitative polymerase chain reaction (PCR) for detection of Leishmania in spleen samples from naturally infected dogs. Vet Parasitol. 2012;184(2-4):133-40.

[8] Mary C, Faraut F, Lascombe L, Dumon H. Quantification of Leishmania infantum DNA by a real-time PCR assay with high sensitivity. J Clin Microbiol. 2004;42(11): 5249-55.

[9] Lainson R, Shaw JJ. Epidemiology and ecology of leishmaniasis in Latin-America. Nature. 1978;273(5664):595-600.

[10] Killick-Kendrick R. The biology and control of phlebotomine sand flies. Clin Dermatol. 1999;17(3):279-89.

[11] Kuhls K, Alam MZ, Cupolillo E, Ferreira GE, Mauricio IL, Oddone R, et al. Comparative microsatellite typing of new world Leishmania infantum reveals low heterogeneity among populations and its recent old world origin. PLoS Negl Trop Dis. 2011;5(6):e1155.

[12] Mauricio IL, Stothard JR, Miles MA. The strange case of Leishmania chagasi. Parasitol Today. 2000;16(5):188-9.

[13] Alvar J, Canavate C, Molina R, Moreno J, Nieto J. Canine leishmaniasis. Adv Parasitol. 2004;57:1-88. 
[14] Bevilacqua PD, Paixao HH, Modena CM, Castro MCPS. Urbanization of visceral leishmaniose in Belo Horizonte, Brazil. Arq Bras Med Vet Zoot. 2001;53:1-8.

[15] Deane LM, Deane MP. Leishmaniose visceral urbana (no cão e no homem) em Sobral, Ceará. O Hospital 1955;47:113-28.

[16] Molina R, Amela C, Nieto J, San-Andres M, Gonzalez F, Castillo JA, et al. Infectivity of dogs naturally infected with Leishmania infantum to colonized Phlebotomus perniciosus. Trans R Soc Trop Med Hyg. 1994;88(4):491-3.

[17] Gramiccia M, Gradoni L. The current status of zoonotic leishmaniases and approaches to disease control. Int J Parasitol. 2005;35(11-12):1169-80.

[18] Dye C. The logic of visceral leishmaniasis control. Am J Trop Med Hyg. 1996;55(2): 125-30.

[19] Coura-Vital W, Marques MJ, Veloso VM, Roatt BM, Aguiar-Soares RD, Reis LE, et al. Prevalence and factors associated with Leishmania infantum infection of dogs from an urban area of Brazil as identified by molecular methods. PLoS Negl Trop Dis. 2011;5(8):e1291.

[20] Podaliri Vulpiani M, Iannetti L, Paganico D, Iannino F, Ferri N. Methods of Control of the Leishmania infantum Dog Reservoir: State of the Art. Vet Med Int. 2011;2011:215964.

[21] Miro G, Cardoso L, Pennisi MG, Oliva G, Baneth G. Canine leishmaniosis--new concepts and insights on an expanding zoonosis: part two. Trends Parasitol. 2008;24(8): 371-7.

[22] Carvalho D, S.; OTMF, D.; BC, Z. MR. An enzyme-linked immunosorbent assay (ELISA) for the detection of IgM antibodies against Leishmania chagasi in dogs. Pesq Vet Bras 2009;29:120-4.

[23] Sundar S, Rai M. Laboratory diagnosis of visceral leishmaniasis. Clinical and diagnostic laboratory immunology. 2002;9(5):951-8.

[24] Moreira MA, Luvizotto MC, Garcia JF, Corbett CE, Laurenti MD. Comparison of parasitological, immunological and molecular methods for the diagnosis of leishmaniasis in dogs with different clinical signs. Vet Parasitol. 2007;145(3-4):245-52.

[25] Ndao M. Diagnosis of parasitic diseases: old and new approaches. Interdiscip Perspect Infect Dis. 2009;2009:278246.

[26] Morales-Yuste M, Morillas-Marquez F, Diaz-Saez V, Baron-Lopez S, Acedo-Sanchez C, Martin-Sanchez J. Epidemiological implications of the use of various methods for the diagnosis of canine leishmaniasis in dogs with different characteristics and in differing prevalence scenarios. Parasitol Res. 2012;111(1):155-64. 
[27] de Paula AA, da Silva AV, Fernandes O, Jansen AM. The use of immunoblot analysis in the diagnosis of canine visceral leishmaniasis in an endemic area of Rio de Janeiro. J Parasitol. 2003;89(4):832-6.

[28] Almeida MA, Jesus EE, Sousa-Atta ML, Alves LC, Berne ME, Atta AM. Clinical and serological aspects of visceral leishmaniasis in northeast Brazilian dogs naturally infected with Leishmania chagasi. Vet Parasitol. 2005;127(3-4):227-32.

[29] Porrozzi R, Santos da Costa MV, Teva A, Falqueto A, Ferreira AL, dos Santos CD, et al. Comparative evaluation of enzyme-linked immunosorbent assays based on crude and recombinant leishmanial antigens for serodiagnosis of symptomatic and asymptomatic Leishmania infantum visceral infections in dogs. Clin Vaccine Immunol. 2007;14(5):544-8.

[30] Quinnell RJ, Carson C, Reithinger R, Garcez LM, Courtenay O. Evaluation of rK39 rapid diagnostic tests for canine visceral leishmaniasis: longitudinal study and metaanalysis. PLoS Negl Trop Dis. 2013;7(1):e1992.

[31] Grimaldi G, Jr., Teva A, Santos CB, Ferreira AL, Falqueto A. The effect of removing potentially infectious dogs on the numbers of canine Leishmania infantum infections in an endemic area with high transmission rates. Am J Trop Med Hyg. 2012;86(6): 966-71.

[32] Courtenay O, Quinnell RJ, Garcez LM, Shaw JJ, Dye C. Infectiousness in a cohort of brazilian dogs: why culling fails to control visceral leishmaniasis in areas of high transmission. J Infect Dis. 2002;186(9):1314-20.

[33] Michalsky EM, Rocha MF, da Rocha Lima AC, Franca-Silva JC, Pires MQ, Oliveira FS, et al. Infectivity of seropositive dogs, showing different clinical forms of leishmaniasis, to Lutzomyia longipalpis phlebotomine sand flies. Vet Parasitol. 2007;147(1-2): 67-76.

[34] Soares MR, de Mendonca IL, do Bonfim JM, Rodrigues JA, Werneck GL, Costa CH. Canine visceral leishmaniasis in Teresina, Brazil: Relationship between clinical features and infectivity for sand flies. Acta Trop. 2011;117(1):6-9.

[35] Maia C, Campino L. Methods for diagnosis of canine leishmaniasis and immune response to infection. Vet Parasitol. 2008;158(4):274-87.

[36] Pennisi MG, Reale S, Giudice SL, Masucci M, Caracappa S, Vitale M, et al. Real-time PCR in dogs treated for leishmaniasis with allopurinol. Veterinary research communications. 2005;29 Suppl 2:301-3.

[37] Martinez V, Quilez J, Sanchez A, Roura X, Francino O, Altet L. Canine leishmaniasis: the key points for qPCR result interpretation. Parasit Vectors. 2011;4:57.

[38] Travi BL, Tabares CJ, Cadena H, Ferro C, Osorio Y. Canine visceral leishmaniasis in Colombia: relationship between clinical and parasitologic status and infectivity for sand flies. Am J Trop Med Hyg. 2001;64(3-4):119-24. 
[39] Shang LM, Peng WP, Jin HT, Xu D, Zhong NN, Wang WL, et al. The prevalence of canine Leishmania infantum infection in Sichuan Province, southwestern China detected by real time PCR. Parasit Vectors. 2011;4(1):173.

[40] Athanasiou LV, Kontos VI, Saridomichelakis MN, Rallis TS, Diakou A. A cross-sectional sero-epidemiological study of canine leishmaniasis in Greek mainland. Acta Trop. 2012;122(3):291-5.

[41] Pastor-Santiago JA, Chavez-Lopez S, Guzman-Bracho C, Flisser A, Olivo-Diaz A. American visceral leishmaniasis in Chiapas, Mexico. Am J Trop Med Hyg. 2012;86(1): 108-14.

[42] Berrahal F, Mary C, Roze M, Berenger A, Escoffier K, Lamouroux D, et al. Canine leishmaniasis: identification of asymptomatic carriers by polymerase chain reaction and immunoblotting. Am J Trop Med Hyg. 1996;55(3):273-7.

[43] Quinnell RJ, Courtenay O, Davidson S, Garcez L, Lambson B, Ramos P, et al. Detection of Leishmania infantum by PCR, serology and cellular immune response in a cohort study of Brazilian dogs. Parasitology. 2001;122(Pt 3):253-61.

[44] Lachaud L, Chabbert E, Dubessay P, Dereure J, Lamothe J, Dedet JP, et al. Value of two PCR methods for the diagnosis of canine visceral leishmaniasis and the detection of asymptomatic carriers. Parasitology. 2002;125(Pt 3):197-207.

[45] Leontides LS, Saridomichelakis MN, Billinis C, Kontos V, Koutinas AF, Galatos AD, et al. A cross-sectional study of Leishmania spp. infection in clinically healthy dogs with polymerase chain reaction and serology in Greece. Vet Parasitol. 2002;109(1-2): 19-27.

[46] Lanotte G, Rioux JA, Perieres J, Vollhardt Y. [Ecology of leishmaniasis in the south of France. 10. Developmental stages and clinical characterization of canine leishmaniasis in relation to epidemiology. (author's transl]. Ann Parasitol Hum Comp. 1979;54(3):277-95.

[47] Pozio E, Gradoni L, Bettini S, Gramiccia M. Leishmaniasis in Tuscany (Italy) V. Further isolation of Leishmania from Rattus rattus in the Province of Grosseto. Ann Trop Med Parasitol. 1981;75(4):393-5.

[48] Moreno J, Alvar J. Canine leishmaniasis: epidemiological risk and the experimental model. Trends Parasitol. 2002;18(9):399-405.

[49] Moreno J, Nieto J, Chamizo C, Gonzalez F, Blanco F, Barker DC, et al. The immune response and PBMC subsets in canine visceral leishmaniasis before, and after, chemotherapy. Vet Immunol Immunopathol. 1999;71(3-4):181-95.

[50] Quinnell RJ, Courtenay O, Garcez LM, Kaye PM, Shaw MA, Dye C, et al. IgG subclass responses in a longitudinal study of canine visceral leishmaniasis. Vet Immunol Immunopathol. 2003;91(3-4):161-8. 
[51] Vercosa BL, Lemos CM, Mendonca IL, Silva SM, de Carvalho SM, Goto H, et al. Transmission potential, skin inflammatory response, and parasitism of symptomatic and asymptomatic dogs with visceral leishmaniasis. BMC Vet Res. 2008;4:45.

[52] Guarga JL, Lucientes J, Peribanez MA, Molina R, Gracia MJ, Castillo JA. Experimental infection of Phlebotomus perniciosus and determination of the natural infection rates of Leishmania infantum in dogs. Acta Trop. 2000;77(2):203-7.

[53] Miles MA, Vexenat JA, Furtado Campos JH, Fonseca de Castro JA. Canine leishmaniasis in Latin América: control strategies for visceral leishmaniasis. Canine Leishmaniasis: an update. 1999;Hoechst Roussel Vet.:46-53.

[54] Moshfe A, Mohebali M, Edrissian G, Zarei Z, Akhoundi B, Kazemi B, et al. Canine visceral leishmaniasis: asymptomatic infected dogs as a source of L. infantum infection. Acta Trop. 2009;112(2):101-5.

[55] Banuls AL, Hide M, Prugnolle F. Leishmania and the leishmaniases: a parasite genetic update and advances in taxonomy, epidemiology and pathogenicity in humans. Adv Parasitol. 2007;64:1-109.

[56] Grimaldi G, Jr., Tesh RB. Leishmaniases of the New World: current concepts and implications for future research. Clin Microbiol Rev. 1993;6(3):230-50.

[57] Gontijo CM, Melo MN. Visceral Leishmaniasis in Brazil: current status, challenges and prospects. . Rev Bras Epidemiol 2004;7(3):338-49.

[58] Ferrer L. International canine Leishmaniasis forum. Proceedings. 1999:6-10.

[59] Srivastava P, Dayama A, Mehrotra S, Sundar S. Diagnosis of visceral leishmaniasis. Trans R Soc Trop Med Hyg. 2011;105(1):1-6.

[60] Alves WA, Bevilacqua PD. Quality of diagnosis of canine visceral leishmaniasis in epidemiological surveys: an epidemic in Belo Horizonte, Minas Gerais, Brazil, 1993 1997. Cad Saúde Pública. 2004;20(1):259-65.

[61] Barrouin-Melo SM, Larangeira DF, Trigo J, Aguiar PH, dos-Santos WL, Pontes-deCarvalho L. Comparison between splenic and lymph node aspirations as sampling methods for the parasitological detection of Leishmania chagasi infection in dogs. Mem Inst Oswaldo Cruz. 2004;99(2):195-7.

[62] Cabral M, O'Grady J, Alexander J. Demonstration of Leishmania specific cell mediated and humoral immunity in asymptomatic dogs. Parasite Immunol. 1992;14(5): 531-9.

[63] Solano-Gallego L, Llull J, Ramos G, Riera C, Arboix M, Alberola J, et al. The Ibizian hound presents a predominantly cellular immune response against natural Leishmania infection. Vet Parasitol. 2000;90(1-2):37-45.

[64] Saridomichelakis MN. Advances in the pathogenesis of canine leishmaniosis: epidemiologic and diagnostic implications. Vet Dermatol. 2009;20(5-6):471-89. 
[65] Benderitter T, Casanova P, Nashkidachvili L, Quilici M. Glomerulonephritis in dogs with canine leishmaniasis. Ann Trop Med Parasitol. 1988;82(4):335-41.

[66] Ciaramella P, Oliva G, Luna RD, Gradoni L, Ambrosio R, Cortese L, et al. A retrospective clinical study of canine leishmaniasis in 150 dogs naturally infected by Leishmania infantum. Vet Rec. 1997;141(21):539-43.

[67] Koutinas AF, Polizopoulou ZS, Saridomichelakis MN, Argyriadis D, Fytianou A, Plevraki KG. Clinical considerations on canine visceral leishmaniasis in Greece: a retrospective study of 158 cases (1989-1996). J Am Anim Hosp Assoc. 1999;35(5):376-83.

[68] Mendonça L, Alves LC, Faustino MAG, Vasconcelos JR. Clinical aspects of visceral Leishmania in naturally infected dogs in the of Teresina, Piaui'. Revista Brasileira Parasitologia Veterinaria. 1998 8(1):23-5.

[69] Shaw SE, Langton DA, Hillman TJ. Canine leishmaniosis in the United Kingdom: a zoonotic disease waiting for a vector? Vet Parasitol. 2009;163(4):281-5.

[70] Solano-Gallego L, Miro G, Koutinas A, Cardoso L, Pennisi MG, Ferrer L, et al. LeishVet guidelines for the practical management of canine leishmaniosis. Parasit Vectors. 2011;4:86.

[71] Ferrer L, Aisa MJ, Roura X, Portus M. Serological diagnosis and treatment of canine leishmaniasis. Vet Rec. 1995;136(20):514-6.

[72] Ordeix L, Solano-Gallego L, Fondevila D, Ferrer L, Fondati A. Papular dermatitis due to Leishmania spp. infection in dogs with parasite-specific cellular immune responses. Vet Dermatol. 2005;16(3):187-91.

[73] Baneth G, Koutinas AF, Solano-Gallego L, Bourdeau P, Ferrer L. Canine leishmaniosis - new concepts and insights on an expanding zoonosis: part one. Trends Parasitol. 2008;24(7):324-30.

[74] Reis AB, Teixeira-Carvalho A, Giunchetti RC, Guerra LL, Carvalho MG, Mayrink W, et al. Phenotypic features of circulating leucocytes as immunological markers for clinical status and bone marrow parasite density in dogs naturally infected by Leishmania chagasi. Clin Exp Immunol. 2006;146(2):303-11.

[75] Tropia de Abreu R, Carvalho M, Carneiro CM, Giunchetti RC, Teixeira-Carvalho A, Martins-Filho OA, et al. Influence of clinical status and parasite load on erythropoiesis and leucopoiesis in dogs naturally infected with Leishmania (Leishmania) chagasi. PLoS One. 2011;6(5):e18873.

[76] Cortese L, Sica M, Piantedosi D, Ruggiero G, Pero ME, Terrazzano G, et al. Secondary immune-mediated thrombocytopenia in dogs naturally infected by Leishmania infantum. Vet Rec. 2009;164(25):778-82.

[77] Reis AB, Teixeira-Carvalho A, Vale AM, Marques MJ, Giunchetti RC, Mayrink W, et al. Isotype patterns of immunoglobulins: hallmarks for clinical status and tissue para- 
site density in Brazilian dogs naturally infected by Leishmania (Leishmania) chagasi. Vet Immunol Immunopathol. 2006;112(3-4):102-16.

[78] Palma G, Gutierrez Y. Laboratory diagnosis of Leishmania. Clin Lab Med. 1991;11(4): 909-22.

[79] de Almeida ME, Steurer FJ, Koru O, Herwaldt BL, Pieniazek NJ, da Silva AJ. Identification of Leishmania spp. by molecular amplification and DNA sequencing analysis of a fragment of rRNA internal transcribed spacer 2. J Clin Microbiol. 2011;49(9): 3143-9.

[80] Paltrinieri S, Ravicini S, Rossi G, Roura X. Serum concentrations of the derivatives of reactive oxygen metabolites (d-ROMs) in dogs with leishmaniosis. Vet J. 2010;186(3): 393-5.

[81] Fraga DB, Solca MS, Silva VM, Borja LS, Nascimento EG, Oliveira GG, et al. Temporal distribution of positive results of tests for detecting Leishmania infection in stray dogs of an endemic area of visceral leishmaniasis in the Brazilian tropics: a 13 years survey and association with human disease. Vet Parasitol. 2012;190(3-4):591-4.

[82] da Silva RN, Amorim AC, Brandao RM, de Andrade HM, Yokoo M, Ribeiro ML, et al. Real-time PCR in clinical practice: a powerful tool for evaluating Leishmania chagasi loads in naturally infected dogs. Ann Trop Med Parasitol. 2010;104(2):137-43.

[83] Pinelli E, Killick-Kendrick R, Wagenaar J, Bernadina W, del Real G, Ruitenberg J. Cellular and humoral immune responses in dogs experimentally and naturally infected with Leishmania infantum. Infect Immun. 1994;62(1):229-35.

[84] Dos-Santos WL, Jesus EE, Paranhos-Silva M, Pereira AM, Santos JC, Baleeiro CO, et al. Associations among immunological, parasitological and clinical parameters in canine visceral leishmaniasis: Emaciation, spleen parasitism, specific antibodies and leishmanin skin test reaction. Vet Immunol Immunopathol. 2008;123(3-4):251-9.

[85] Ferrer L. Clinical aspects of canine leishmaniasis. International Canine Leishmaniasis forum, Barcelona. 1999:6-10.

[86] da Silva ES, van der Meide WF, Schoone GJ, Gontijo CM, Schallig HD, Brazil RP. Diagnosis of canine leishmaniasis in the endemic area of Belo Horizonte, Minas Gerais, Brazil by parasite, antibody and DNA detection assays. Vet Res Commun. 2006;30(6): 637-43.

[87] Boarino A, Scalone A, Gradoni L, Ferroglio E, Vitale F, Zanatta R, et al. Development of recombinant chimeric antigen expressing immunodominant B epitopes of Leishmania infantum for serodiagnosis of visceral leishmaniasis. Clin Diagn Lab Immunol. 2005;12(5):647-53.

[88] Lira RA, Cavalcanti MP, Nakazawa M, Ferreira AG, Silva ED, Abath FG, et al. Canine visceral leishmaniosis: a comparative analysis of the EIE-leishmaniose-visceral- 
canina-Bio-Manguinhos and the IFI-leishmaniose-visceral-canina-Bio-Manguinhos kits. Vet Parasitol. 2006;137(1-2):11-6.

[89] Ferroglio E, Centaro E, Mignone W, Trisciuoglio A. Evaluation of an ELISA rapid device for the serological diagnosis of Leishmania infantum infection in dog as compared with immunofluorescence assay and Western blot. Vet Parasitol. 2007;144(1-2):162-6.

[90] Alves AS, Mouta-Confort E, Figueiredo FB, Oliveira RV, Schubach AO, Madeira MF. Evaluation of serological cross-reactivity between canine visceral leishmaniasis and natural infection by Trypanosoma caninum. Res Vet Sci. 2012;93(3):1329-33.

[91] Reithinger R, Davies CR. Canine leishmaniasis: novel strategies for control. Trends Parasitol. 2002;18(7):289-90.

[92] Figueiredo MM, Moura EP, Costa MM, Ribeiro VM, Michalick MS, Tafuri WL, et al. Histopathological and parasitological investigations of ear healthy skin of dogs naturally and experimentally infected with Leishmania (Leishmania) chagasi. Histol Histopathol. 2010;25(7):877-87.

[93] el Harith A, Slappendel RJ, Reiter I, van Knapen F, de Korte P, Huigen E, et al. Application of a direct agglutination test for detection of specific anti-Leishmania antibodies in the canine reservoir. J Clin Microbiol. 1989;27(10):2252-7.

[94] el Safi SH, Evans DA. A comparison of the direct agglutination test and enzymelinked immunosorbent assay in the sero-diagnosis of leishmaniasis in the Sudan. Trans R Soc Trop Med Hyg. 1989;83(3):334-7.

[95] Babakhan L, Mohebali M, Akhoundi B, Edrissian GH, Keshavarz H. Rapid detection of Leishmania infantum infection in dogs: a comparative study using fast agglutination screening test (FAST) and direct agglutination test (DAT) in Iran. Parasitol Res. 2009;105(3):717-20.

[96] Schallig HD, Canto-Cavalheiro M, da Silva ES. Evaluation of the direct agglutination test and the rK39 dipstick test for the sero-diagnosis of visceral leishmaniasis. Mem Inst Oswaldo Cruz. 2002;97(7):1015-8.

[97] Sundar S, Maurya R, Singh RK, Bharti K, Chakravarty J, Parekh A, et al. Rapid, noninvasive diagnosis of visceral leishmaniasis in India: comparison of two immunochromatographic strip tests for detection of anti-K39 antibody. J Clin Microbiol. 2006;44(1):251-3.

[98] Mohammadiha A, Haghighi A, Mohebali M, Mahdian R, Abadi AR, Zarei Z, et al. Canine visceral leishmaniasis: a comparative study of real-time PCR, conventional PCR, and direct agglutination on sera for the detection of Leishmania infantum infection. Vet Parasitol. 2013;192(1-3):83-90.

[99] Moreira ED, Jr., Mendes de Souza VM, Sreenivasan M, Nascimento EG, Pontes de Carvalho L. Assessment of an optimized dog-culling program in the dynamics of canine Leishmania transmission. Vet Parasitol. 2004;122(4):245-52. 
[100] Kar K. Serodiagnosis of leishmaniasis. Crit Rev Microbiol. 1995;21(2):123-52.

[101] Candido TC, Perri SH, Gerzoschkwitz Tde O, Luvizotto MC, de Lima VM. Comparative evaluation of enzyme-linked immunosorbent assay based on crude and purified antigen in the diagnosis of canine visceral leishmaniasis in symptomatic and oligosymptomatic dogs. Vet Parasitol. 2008;157(3-4):175-81.

[102] Coelho EA, Ramirez L, Costa MA, Coelho VT, Martins VT, Chavez-Fumagalli MA, et al. Specific serodiagnosis of canine visceral leishmaniasis using Leishmania species ribosomal protein extracts. Clin Vaccine Immunol. 2009;16(12):1774-80.

[103] Silva DA, Madeira MF, Teixeira AC, de Souza CM, Figueiredo FB. Laboratory tests performed on Leishmania seroreactive dogs euthanized by the leishmaniasis control program. Vet Parasitol. 2011;179(1-3):257-61.

[104] Nolan TJ, Herman R. Effects of long-term in vitro cultivation on Leishmania donovani promastigotes. J Protozool. 1985;32(1):70-5.

[105] Faria AR, Costa MM, Giusta MS, Grimaldi G, Jr., Penido ML, Gazzinelli RT, et al. High-throughput analysis of synthetic peptides for the immunodiagnosis of canine visceral leishmaniasis. PLoS Negl Trop Dis. 2011;5(9):e1310.

[106] Oliveira GG, Magalhaes FB, Teixeira MC, Pereira AM, Pinheiro CG, Santos LR, et al. Characterization of novel Leishmania infantum recombinant proteins encoded by genes from five families with distinct capacities for serodiagnosis of canine and human visceral leishmaniasis. Am J Trop Med Hyg. 2011;85(6):1025-34.

[107] Scalone A, De Luna R, Oliva G, Baldi L, Satta G, Vesco G, et al. Evaluation of the Leishmania recombinant $\mathrm{K} 39$ antigen as a diagnostic marker for canine leishmaniasis and validation of a standardized enzyme-linked immunosorbent assay. Vet Parasitol. 2002;104(4):275-85.

[108] Rosati S, Ortoffi M, Profiti M, Mannelli A, Mignone W, Bollo E, et al. Prokaryotic expression and antigenic characterization of three recombinant Leishmania antigens for serological diagnosis of canine leishmaniasis. Clin Diagn Lab Immunol. 2003;10(6): 1153-6.

[109] de Souza CM, Silva ED, Ano Bom AP, Bastos RC, Nascimento HJ, da Silva Junior JG. Evaluation of an ELISA for canine leishmaniasis immunodiagnostic using recombinant proteins. Parasite Immunol. 2012;34(1):1-7.

[110] de Lima VM, Fattori KR, Michelin Ade F, da Silveira Neto L, Vasconcelos Rde O. Comparison between ELISA using total antigen and immunochromatography with antigen rK39 in the diagnosis of canine visceral leishmaniasis. Vet Parasitol. 2010;173(3-4):330-3.

[111] Vuylsteke B, Semde G, Sika L, Crucitti T, Ettiegne Traore V, Buve A, et al. HIV and STI prevalence among female sex workers in Cote d'Ivoire: why targeted prevention programs should be continued and strengthened. PLoS One. 2012;7(3):e32627. 
[112] Wu W, Huang L, Mendez S. A live Leishmania major vaccine containing CpG motifs induces the de novo generation of Th17 cells in C57BL/6 mice. Eur J Immunol. 2010;40(9):2517-27.

[113] Badaro R, Benson D, Eulalio MC, Freire M, Cunha S, Netto EM, et al. rK39: a cloned antigen of Leishmania chagasi that predicts active visceral leishmaniasis. J Infect Dis. 1996;173(3):758-61.

[114] Burns JM, Jr., Shreffler WG, Benson DR, Ghalib HW, Badaro R, Reed SG. Molecular characterization of a kinesin-related antigen of Leishmania chagasi that detects specific antibody in African and American visceral leishmaniasis. Proc Natl Acad Sci U S A. 1993;90(2):775-9.

[115] de Carvalho LP, Soto M, Jeronimo S, Dondji B, Bacellar O, Luz V, et al. Characterization of the immune response to Leishmania infantum recombinant antigens. Microbes Infect. 2003;5(1):7-12.

[116] Ferroglio E, Zanet S, Mignone W, Poggi M, Trisciuoglio A, Bianciardi P. Evaluation of a rapid device for serological diagnosis of Leishmania infantum infection in dogs as an alternative to immunofluorescence assay and Western blotting. Clin Vaccine Immunol. 2013;20(5):657-9.

[117] Kumar D, Khanal B, Tiwary P, Mudavath SL, Tiwary NK, Singh R, et al. Comparative evaluation of blood and serum samples in rapid immunochromatographic tests for visceral leishmaniasis. J Clin Microbiol. 2013;51(12):3955-9.

[118] Lemos EM, Laurenti MD, Moreira MA, Reis AB, Giunchetti RC, Raychaudhuri S, et al. Canine visceral leishmaniasis: performance of a rapid diagnostic test (Kalazar Detect) in dogs with and without signs of the disease. Acta Trop. 2008;107(2):205-7.

[119] Mettler M, Grimm F, Capelli G, Camp H, Deplazes P. Evaluation of enzyme-linked immunosorbent assays, an immunofluorescent-antibody test, and two rapid tests (immunochromatographic-dipstick and gel tests) for serological diagnosis of symptomatic and asymptomatic Leishmania infections in dogs. J Clin Microbiol. 2005;43(11): 5515-9.

[120] Otranto D, Paradies P, Sasanelli M, Spinelli R, Brandonisio O. Rapid immunochromatographic test for serodiagnosis of canine leishmaniasis. J Clin Microbiol. 2004;42(6):2769-70.

[121] Otranto D, Paradies P, Sasanelli M, Leone N, de Caprariis D, Chirico J, et al. Recombinant K39 dipstick immunochromatographic test: a new tool for the serodiagnosis of canine leishmaniasis. J Vet Diagn Invest. 2005;17(1):32-7.

[122] Mohebali M, Khamesipour A, Mobedi I, Zarei Z, Hashemi-Fesharki R. Double-blind randomized efficacy field trial of alum precipitated autoclaved Leishmania major vaccine mixed with BCG against canine visceral leishmaniasis in Meshkin-Shahr district, I.R. Iran. Vaccine. 2004;22(29-30):4097-100. 
[123] Reithinger R, Quinnell RJ, Alexander B, Davies CR. Rapid detection of Leishmania infantum infection in dogs: comparative study using an immunochromatographic dipstick test, enzyme-linked immunosorbent assay, and PCR. J Clin Microbiol. 2002;40(7):2352-6.

[124] Costa MM, Penido M, dos Santos MS, Doro D, de Freitas E, Michalick MS, et al. Improved canine and human visceral leishmaniasis immunodiagnosis using combinations of synthetic peptides in enzyme-linked immunosorbent assay. PLoS Negl Trop Dis. 2012;6(5):e1622.

[125] Pattabhi S, Whittle J, Mohamath R, El-Safi S, Moulton GG, Guderian JA, et al. Design, development and evaluation of rK28-based point-of-care tests for improving rapid diagnosis of visceral leishmaniasis. PLoS Negl Trop Dis. 2010;4(9).

[126] de Paiva Cavalcanti M, Felinto de Brito ME, de Souza WV, de Miranda Gomes Y, Abath FG. The development of a real-time PCR assay for the quantification of Leishmania infantum DNA in canine blood. Vet J. 2009;182(2):356-8.

[127] Bastien P, Procop GW, Reischl U. Quantitative real-time PCR is not more sensitive than "conventional" PCR. J Clin Microbiol. 2008;46(6):1897-900.

[128] Lachaud L, Chabbert E, Dubessay P, Reynes J, Lamothe J, Bastien P. Comparison of various sample preparation methods for PCR diagnosis of visceral leishmaniasis using peripheral blood. J Clin Microbiol. 2001;39(2):613-7.

[129] Fisa R, Riera C, Gallego M, Manubens J, Portus M. Nested PCR for diagnosis of canine leishmaniosis in peripheral blood, lymph node and bone marrow aspirates. Vet Parasitol. 2001;99(2):105-11.

[130] Francino O, Altet L, Sanchez-Robert E, Rodriguez A, Solano-Gallego L, Alberola J, et al. Advantages of real-time PCR assay for diagnosis and monitoring of canine leishmaniosis. Vet Parasitol. 2006;137(3-4):214-21.

[131] Galletti E, Bonilauri P, Bardasi L, Fontana MC, Ramini M, Renzi M, et al. Development of a minor groove binding probe based real-time PCR for the diagnosis and quantification of Leishmania infantum in dog specimens. Res Vet Sci. 2011;91(2):243-5.

[132] Maia C, Ramada J, Cristovao JM, Goncalves L, Campino L. Diagnosis of canine leishmaniasis: conventional and molecular techniques using different tissues. Vet J. 2009;179(1):142-4.

[133] Manna L, Vitale F, Reale S, Caracappa S, Pavone LM, Morte RD, et al. Comparison of different tissue sampling for PCR-based diagnosis and follow-up of canine visceral leishmaniosis. Vet Parasitol. 2004;125(3-4):251-62.

[134] Ferreira Sde A, Almeida GG, Silva Sde O, Vogas GP, Fujiwara RT, de Andrade AS, et al. Nasal, oral and ear swabs for canine visceral leishmaniasis diagnosis: new practical approaches for detection of Leishmania infantum DNA. PLoS Negl Trop Dis. 2013;7(4):e2150. 
[135] Belinchon-Lorenzo S, Iniesta V, Parejo JC, Fernandez-Cotrina J, Munoz-Madrid R, Soto $\mathrm{M}$, et al. Detection of Leishmania infantum kinetoplast minicircle DNA by Real Time PCR in hair of dogs with leishmaniosis. Vet Parasitol. 2013;192(1-3):43-50.

[136] Lombardo G, Pennisi MG, Lupo T, Migliazzo A, Capri A, Solano-Gallego L. Detection of Leishmania infantum DNA by real-time PCR in canine oral and conjunctival swabs and comparison with other diagnostic techniques. Vet Parasitol. 2012;184(1): $10-7$.

[137] Quaresma PF, Murta SM, Ferreira Ede C, da Rocha-Lima AC, Xavier AA, Gontijo CM. Molecular diagnosis of canine visceral leishmaniasis: identification of Leishmania species by PCR-RFLP and quantification of parasite DNA by real-time PCR. Acta Trop. 2009;111(3):289-94.

[138] Andrade HM, de Toledo Vde P, Marques MJ, Franca Silva JC, Tafuri WL, Mayrink $\mathrm{W}$, et al. Leishmania (Leishmania) chagasi is not vertically transmitted in dogs. Vet Parasitol. 2002;103(1-2):71-81.

[139] Ferreira Sde A, Ituassu LT, de Melo MN, de Andrade AS. Evaluation of the conjunctival swab for canine visceral leishmaniasis diagnosis by PCR-hybridization in Minas Gerais State, Brazil. Vet Parasitol. 2008;152(3-4):257-63.

[140] Antinori S, Calattini S, Longhi E, Bestetti G, Piolini R, Magni C, et al. Clinical use of polymerase chain reaction performed on peripheral blood and bone marrow samples for the diagnosis and monitoring of visceral leishmaniasis in HIV-infected and HIVuninfected patients: a single-center, 8-year experience in Italy and review of the literature. Clin Infect Dis. 2007;44(12):1602-10.

[141] Reale S, Maxia L, Vitale F, Glorioso NS, Caracappa S, Vesco G. Detection of Leishmania infantum in dogs by PCR with lymph node aspirates and blood. J Clin Microbiol. 1999;37(9):2931-5.

[142] Lachaud L, Marchergui-Hammami S, Chabbert E, Dereure J, Dedet JP, Bastien P. Comparison of six PCR methods using peripheral blood for detection of canine visceral leishmaniasis. J Clin Microbiol. 2002;40(1):210-5.

[143] Rodriguez-Cortes A, Ojeda A, Lopez-Fuertes L, Timon M, Altet L, Solano-Gallego L, et al. A long term experimental study of canine visceral leishmaniasis. International journal for parasitology. 2007;37(6):683-93.

[144] Manna L, Gravino AE, Picillo E, Decaro N, Buonavoglia C. Leishmania DNA quantification by real-time PCR in naturally infected dogs treated with miltefosine. Ann NY Acad Sci. 2008;1149:358-60.

[145] Manna L, Reale S, Vitale F, Gravino AE. Evidence for a relationship between Leishmania load and clinical manifestations. Res Vet Sci. 2009;87(1):76-8.

[146] Maia C, Nunes M, Cristovao J, Campino L. Experimental canine leishmaniasis: clinical, parasitological and serological follow-up. Acta Trop. 2010;116(3):193-9. 
[147] Naranjo C, Fondevila D, Altet L, Francino O, Rios J, Roura X, et al. Evaluation of the presence of Leishmania spp. by real-time PCR in the lacrimal glands of dogs with leishmaniosis. Vet J. 2011.

[148] Saldarriaga OA, Travi BL, Park W, Perez LE, Melby PC. Immunogenicity of a multicomponent DNA vaccine against visceral leishmaniasis in dogs. Vaccine. 2006;24(11): 1928-40.

[149] Reis LE, Coura-Vital W, Roatt BM, Bouillet LE, Ker HG, Fortes de Brito RC, et al. Molecular diagnosis of canine visceral leishmaniasis: a comparative study of three methods using skin and spleen from dogs with natural Leishmania infantum infection. Vet Parasitol. 2013;197(3-4):498-503.

[150] Leveille R, Partington BP, Biller DS, Miyabayashi T. Complications after ultrasoundguided biopsy of abdominal structures in dogs and cats: 246 cases (1984-1991). Journal of the American Veterinary Medical Association. 1993;203(3):413-5.

[151] Barrouin-Melo SM, Larangeira DF, de Andrade Filho FA, Trigo J, Juliao FS, Franke $\mathrm{CR}$, et al. Can spleen aspirations be safely used for the parasitological diagnosis of canine visceral leishmaniosis? A study on assymptomatic and polysymptomatic animals. Vet J. 2006;171(2):331-9.

[152] Watson AT, Penninck D, Knoll JS, Keating JH, Sutherland-Smith J. Safety and correlation of test results of combined ultrasound-guided fine-needle aspiration and needle core biopsy of the canine spleen. Veterinary radiology \& ultrasound : the official journal of the American College of Veterinary Radiology and the International Veterinary Radiology Association. 2011;52(3):317-22.

[153] Carvalho D, Oliveira TMFS, Baldani CD, Machado RZ. An enzyme-linked immunosorbent assay (ELISA) for the detection of IgM antibodies against Leishmania chagasi in dogs. Pesq Vet Bras 2009;29:120-4.

[154] Aoun O, Mary C, Roqueplo C, Marie JL, Terrier O, Levieuge A, et al. Canine leishmaniasis in south-east of France: screening of Leishmania infantum antibodies (western blotting, ELISA) and parasitaemia levels by PCR quantification. Vet Parasitol. 2009;166(1-2):27-31.

[155] de Almeida Ferreira S, Leite RS, Ituassu LT, Almeida GG, Souza DM, Fujiwara RT, et al. Canine skin and conjunctival swab samples for the detection and quantification of Leishmania infantum DNA in an endemic urban area in Brazil. PLoS Negl Trop Dis. 2012;6(4):e1596.

[156] Di Muccio T, Veronesi F, Antognoni MT, Onofri A, Piergili Fioretti D, Gramiccia M. Diagnostic value of conjunctival swab sampling associated with nested PCR for different categories of dogs naturally exposed to Leishmania infantum infection. J Clin Microbiol. 2012;50(8):2651-9. 
[157] Nasereddin A, Ereqat S, Azmi K, Baneth G, Jaffe CL, Abdeen Z. Serological survey with PCR validation for canine visceral leishmaniasis in northern Palestine. J Parasitol. 2006;92(1):178-83.

[158] Strauss-Ayali D, Jaffe CL, Burshtain O, Gonen L, Baneth G. Polymerase chain reaction using noninvasively obtained samples, for the detection of Leishmania infantum DNA in dogs. J Infect Dis. 2004;189(9):1729-33.

[159] Leite RS, Ferreira Sde A, Ituassu LT, de Melo MN, de Andrade AS. PCR diagnosis of visceral leishmaniasis in asymptomatic dogs using conjunctival swab samples. Vet Parasitol. 2010;170(3-4):201-6.

[160] Solano-Gallego L, Rodriguez-Cortes A, Trotta M, Zampieron C, Razia L, Furlanello $\mathrm{T}$, et al. Detection of Leishmania infantum DNA by fret-based real-time PCR in urine from dogs with natural clinical leishmaniosis. Vet Parasitol. 2007;147(3-4):315-9.

[161] Naranjo C, Fondevila D, Altet L, Francino O, Rios J, Roura X, et al. Evaluation of the presence of Leishmania spp. by real-time PCR in the lacrimal glands of dogs with leishmaniosis. Vet J. 2012;193(1):168-73.

[162] Manna L, Reale S, Picillo E, Vitale F, Gravino AE. Urine sampling for real-time polymerase chain reaction based diagnosis of canine leishmaniasis. J Vet Diagn Invest. 2008;20(1):64-7.

[163] Rolao N, Cortes S, Rodrigues OR, Campino L. Quantification of Leishmania infantum parasites in tissue biopsies by real-time polymerase chain reaction and polymerase chain reaction-enzyme-linked immunosorbent assay. J Parasitol. 2004;90(5):1150-4. 
